Published in final edited form as:

Апnи Rev Neurosci. 2009 ; 32: 1-32. doi:10.1146/annurev.neuro.051508.135531.

\title{
Neuropathic Pain:
}

\section{A Maladaptive Response of the Nervous System to Damage}

Michael Costigan, Joachim Scholz, and Clifford J. Woolf

Neural Plasticity Research Group, Department of Anesthesia and Critical Care, Massachusetts

General Hospital and Harvard Medical School, Boston, Massachusetts 02129

\begin{abstract}
Neuropathic pain is triggered by lesions to the somatosensory nervous system that alter its structure and function so that pain occurs spontaneously and responses to noxious and innocuous stimuli are pathologically amplified. The pain is an expression of maladaptive plasticity within the nociceptive system, a series of changes that constitute a neural disease state. Multiple alterations distributed widely across the nervous system contribute to complex pain phenotypes. These alterations include ectopic generation of action potentials, facilitation and disinhibition of synaptic transmission, loss of synaptic connectivity and formation of new synaptic circuits, and neuroimmune interactions. Although neural lesions are necessary, they are not sufficient to generate neuropathic pain; genetic polymorphisms, gender, and age all influence the risk of developing persistent pain. Treatment needs to move from merely suppressing symptoms to a disease-modifying strategy aimed at both preventing maladaptive plasticity and reducing intrinsic risk.
\end{abstract}

\section{Keywords}

neural plasticity; synaptic facilitation; disinhibition; neuroimmune interaction; pain phenotype

\section{INTRODUCTION}

Diseases affecting the somatosensory nervous system can provoke lasting pain in addition to sensory deficits. (See sidebar, Neuropathic Pain Symtoms.) Here we review the neurobiological mechanisms that operate at multiple sites within the nervous system to produce neuropathic hypersensitivity. To understand the nature and specific features of neuropathic pain (defined in Treede et al. 2008), we first compare it with the other pain syndromes: nociceptive, inflammatory, and dysfunctional pain.

\section{NOCICEPTIVE PAIN}

To guard against tissue injury, it is imperative that the body is aware of potentially damaging stimuli. This awareness is achieved by a noxious stimulus-detecting sensory system (Figure 1). Nociceptive pain is an alarm mediated by high-threshold unmyelinated $C$ or thinly

Copyright $(92009$ by Annual Reviews. All rights reserved email: mcostigan@partners.org, scholz.joachim@mgh.harvard.edu, cwoolf@ partners.org. DISCLOSURE STATEMENTS

C.W. is Chairman of the scientific advisory board of Solace Pharmaceuticals, which develops therapies for neuropathic pain and has licensed submitted patents on tetrahydrobiopterin synthesis and polymorphisms in GCH1 from the Massachusetts General Hospital. He is or has been a consultant/advisor to Hydra Biosciences, Pfizer, Abbott, and GlaxoSmithKline and has received research support from Pfizer and GlaxoSmithKline. J.S. is or has been a consultant to Pfizer and receives or has received research support from Pfizer and GlaxoSmithKline. M.C. is a consultant to Solace Pharmaceuticals. 
myelinated $\mathrm{A} \delta$ primary sensory neurons that feed into nociceptive pathways of the central nervous system (CNS) (Woolf \& Ma 2007). These nociceptor neurons express specialized transducer ion channel receptors, mainly transient receptor potential (TRP) channels, tuned to respond to intense thermal or mechanical stimuli as well as exogenous and endogenous chemical mediators (Dhaka et al. 2006). For nociceptive pain to subserve its protective function, the sensation must be so unpleasant that it cannot be ignored. Nociceptive pain occurs in response to noxious stimuli and continues only in the maintained presence of noxious stimuli (Figures 1 and 2). It alerts us to external stimuli, such as pinprick or excessive heat, and internal stimuli, such as myocardial ischemia in patients with coronary artery disease. Certain diseases may generate recurrent or ongoing noxious stimuli to produce chronic nociceptive pain. One example is osteoarthritis: Normal weight bearing in the presence of mechanical deformation of the joint may produce sufficient force to activate high-threshold synovial mechanoreceptors (Torres et al. 2006).

Loss of nociception, as in hereditary disorders associated with congenital insensitivity to pain (Cox et al. 2006, Indo 2001), leads to repeated injury and inadvertent self mutilation, illustrating the highly adaptive function of nociceptive pain.

\section{INFLAMMATORY PAIN}

This pain occurs in response to tissue injury and the subsequent inflammatory response. Here the imperative shifts from protecting the body against a potentially damaging noxious stimulus to addressing the consequences of damage. To aid healing and repair of the injured body part, the sensory nervous system undergoes a profound change in its responsiveness; normally innocuous stimuli now produce pain and responses to noxious stimuli are both exaggerated and prolonged (Juhl et al. 2008) (Figure 1). Heightened sensitivity occurs within the inflamed area and in contiguous noninflamed areas as a result of plasticity in peripheral nociceptors and central nociceptive pathways (Huang et al. 2006, Hucho \& Levine 2007, Woolf \& Salter 2000). Because the pain system after inflammation is sensitized, it no longer acts just as a detector for noxious stimuli but can be activated also by low-threshold innocuous inputs (Figures 1 and 2). Ablation of a specific set of nociceptor neurons, those expressing the tetrodotoxin-resistant sodium channel Nav1.8, eliminates inflammatory pain but leaves neuropathic pain intact, indicating a fundamental difference in the neuronal pathways responsible for these pain states (Abrahamsen et al. 2008). Typically, inflammatory pain disappears after resolution of the initial tissue injury. However, in chronic disorders such as rheumatoid arthritis the pain persists for as long as inflammation is active (Michaud et al. 2007).

\section{MECHANISMS COMMON TO DIFFERENT CHRONIC PAIN STATES}

Although inflammatory, dysfunctional, and neuropathic pain are distinct in terms of their etiology and clinical features (Figure 1), they have some mechanisms in common.

\section{NEUROPATHIC PAIN SYMPTOMS}

Imagine an excruciating pain every time clothes touch your skin, spontaneous burning that feels like boiling water, bursts of "pins and needles" in your feet when you walk, a continuous crushing pain after an amputation as if your phantom foot is being squeezed, a band of searing pain around your body at the level at which you have lost all sensation after a spinal cord injury. These are just some of the devastating symptoms patients with neuropathic pain may experience. 


\section{Immune Mediator Detection}

Nociceptors respond directly to cytokines, chemokines, and other inflammatory mediators produced in inflamed tissues (Binshtok et al. 2008). Interleukin-1 $\beta$ (IL1 $\beta$ ), tumor necrosis factor (TNF), bradykinin, and nerve growth factor elicit action potential discharge by increasing sodium and calcium currents at the nociceptor peripheral terminal. After neural damage, these same inflammatory mediators are produced by peripheral immune cells and microglia in the spinal cord and contribute to neuropathic pain by activating nociceptive neurons.

\section{Peripheral Sensitization}

Inflammatory mediators activate intracellular signal transduction pathways in the nociceptor terminal, prompting an increase in the production, transport, and membrane insertion of transducer channels and voltage-gated ion channels. The threshold for activation is reduced and membrane excitability increases (Figure 2). A reduction in thermal and mechanical pain thresholds also occurs in some patients with peripheral nerve lesions, which might reflect nociceptor sensitization owing to increased membrane excitability without inflammation (irritable nociceptors) (Fields et al. 1998).

\section{Central Sensitization}

Central sensitization, a form of use-dependent synaptic plasticity, is a major pathophysiological mechanism common to inflammatory, neuropathic, and dysfunctional pain (Figure 2). Activity generated by nociceptors during inflammation produces rapid-onset homo- and heterosynaptic facilitation in the dorsal horn of the spinal cord. In neuropathic pain, ongoing activity originating in injured nerves is the trigger for central sensitization. In dysfunctional pain, the trigger is unclear. Central sensitization resembles activity-dependent synaptic plasticity in the cortex with involvement of various synaptic modulators and excitatory amino acids, alterations in ion channel kinetics and properties, increased density of ionotropic receptors, and activation of kinases pre- and post-synaptically. The increase in synaptic strength enables previously subthreshold inputs to activate nociceptive neurons, reducing their threshold, enhancing their responsiveness, and expanding their receptive fields. Homosynaptic facilitation of nociceptor inputs in the spinal cord is a form of long-term potentiation (LTP). For heterosynaptic facilitation, the initial input that triggers nociceptor activation is different from the facilitated input. Low-threshold afferents convert to pain drivers, and input outside the injury site is recruited.

\section{DYSFUNCTIONAL PAIN}

The remaining two major pain states, neuropathic pain and a group of clinical syndromes that can best be called dysfunctional pain, are maladaptive in the sense that the pain neither protects nor supports healing and repair (Figure 1). Instead, these pain syndromes are caused by a malfunction of the somatosensory apparatus itself, and this malfunction can be considered a disease in its own right. Dysfunctional pain occurs in situations in which there is no identifiable noxious stimulus nor any detectable inflammation or damage to the nervous system. It is unclear in most cases what causes the manifestation or persistence of dysfunctional pain. In conditions such as fibromyalgia, irritable bowel syndrome, and interstitial cystitis, the pain appears to result from an autonomous amplification of nociceptive signals inside the CNS (Nielsen et al. 2008,Staud \& Rodriguez 2006) with a disturbed balance of excitation and inhibition in central circuits (Julien et al. 2005) and altered sensory processing that can be detected by functional imaging (Staud et al. 2008). Dysfunctional pain syndromes share some features of neuropathic pain: temporal summation with a progressive buildup in pain in response to repeated stimuli (windup), spatial diffuseness, and reduced pain thresholds (Staud et al. 2007). 
Primary erythermalgia and paroxysmal extreme pain disorder, which are caused by gain-offunction mutations in the Nav1.7 voltage-gated sodium channel (Drenth \& Waxman 2007), may be considered peripherally mediated dysfunctional pain, but here the molecular causes are known. These mutations are hereditary channelopathies of the peripheral nervous system, which cause pain by ectopic activity of primary sensory neurons due to increased membrane excitability in the absence of axonal lesions or demyelination.

\section{NEUROPATHIC PAIN}

Pain and loss of function are intimately associated with the reaction of the nervous system to neural damage, and both provide important diagnostic clues that such damage has occurred. Peripheral neuropathic pain results from lesions to the peripheral nervous system (PNS) caused by mechanical trauma, metabolic diseases, neurotoxic chemicals, infection, or tumor invasion and involves multiple pathophysiological changes both within the PNS and in the CNS (Dworkin et al. 2003, Woolf \& Mannion 1999). Central neuropathic pain most commonly results from spinal cord injury, stroke, or multiple sclerosis (Ducreux et al. 2006). The conventional approach to neuropathic pain has been to classify and treat it on the basis of the underlying disease (Dworkin et al. 2007). However, such an etiological approach does not capture the essential feature of neuropathic pain, which is the manifestation of maladaptive plasticity in the nervous system. The primary disease and the neural damage it causes are only the initiators of a cascade of changes that lead to and sustain neuropathic pain. Although treatment targeted at the primary pathology is obviously essential, understanding the mechanisms responsible for the maladaptive plasticity offers specific therapeutic opportunities to prevent the development of neuropathic hypersensitivity and normalize function in established neuropathic pain.

\section{Transformation of Acute Neural Injury to Neuropathic Pain}

Once neuropathic pain is generated, the sensory hypersensitivity typically persists for prolonged periods, even though the original etiological cause may have long since disappeared, as after nerve trauma. The syndrome can nevertheless progress if the primary disease, such as diabetes mellitus or nerve compression, continues to damage the nervous system. Neuropathic pain is not an inevitable consequence of neural lesions, though. On the contrary, the pain associated with acute neural damage usually transitions to chronic neuropathic pain in a minority of patients. This transition to chronicity is most obvious after surgical nerve lesions where the extent and timing of the lesion are defined (Kehlet et al. 2006).

For damage of a relatively small nerve, such as the ilioinguinal nerve during hernia repair, the risk of persistent (more than two years) pain is on the order of $\sim 5 \%$ (Kalliomaki et al. 2008), whereas sectioning a large nerve, such as the sciatic nerve or multiple intercostal nerves during thoracotomy, produces sustained neuropathic pain in 30\%-60\% of patients (Ketz 2008, Maguire et al. 2006). Understanding why one individual develops chronic pain and another with an effectively identical lesion is spared is obviously crucial to developing strategies to abort such transitions. Injury such as brachial avulsion during birth does not produce pain in neonates (Anand \& Birch 2002), whereas $~ 40 \%$ of adults develop severe chronic pain when subjected to the same injury (Htut et al. 2006), indicating that neuropathic pain depends in some way on the maturity of the nervous system (Moss et al. 2007).

Epidemiological studies on the prevalence of neuropathic pain indicate a high incidence ( 5\%) (Bouhassira et al. 2008, Dieleman et al. 2008, Torrance et al. 2006). Associated risk factors include gender, age, and anatomical site of the injury. Smaller studies on persistent neuropathic pain after surgery indicate that pain at the time of surgery and the severity of acute postoperative pain increase the incidence of chronic pain (Poleshuck et al. 2006), although it is unclear whether the risk increases because acute postoperative pain was inadequately 
managed or individuals who have a higher inherent susceptibility to developing persistent pain also suffer more intense acute pain. Emotional and cognitive factors influence how patients react to chronic pain (Haythornthwaite et al. 2003), but it is much less certain if these factors contribute to the risk of developing pain.

Two interdependent processes appear to be major general contributors to developing neuropathic pain: the balance between compensatory and decompensatory reactions of the nervous system to neural damage, and a genetic background that either enhances or protects an individual from the establishment of neuropathic pain. Many of the changes that occur in response to neural injury are potentially adaptive: removal of cell and myelin debris, changes in receptors that counterbalance the loss of input, other alterations that dampen ion fluxes and metabolic stress after the acute injury, recruitment of antiapoptotic survival strategies to prevent neuronal cell death, induction of axonal growth and sprouting, synaptic remodeling, and remyelination (Benn \& Woolf 2004, Cafferty et al. 2008). However, many are clearly maladaptive: abnormal stimulus thresholds and sensitivity, ectopic impulse generation, conduction slowing or block, reduced inhibition, inappropriate connectivity, abortive growth, neuronal loss, and glial scarring. Some of these changes occur early after the initial damage and participate in the induction phase of neuropathic pain, others develop later and help maintain the pain, and in some individuals, there may occasionally be a slow resolution.

\section{MECHANISMS OF NEUROPATHIC PAIN}

Major known mechanisms responsible for peripheral neuropathic pain are represented in Figure 3 (Campbell \& Meyer 2006,Finnerup et al. 2007a). Much less is understood aboutthe mechanisms underlying central neuropathic pain (Crown et al. 2008,Detloff et al. 2008,Finnerup et al. 2007b).

\section{Ectopic Impulse Generation}

An important feature of neuropathic pain is pain in the absence of an identifiable stimulus. Spontaneous pain arises as a result of ectopic action potential generation within the nociceptive pathways and does not originate in peripheral terminals in response to a stimulus (Figures 2 and 3). Theoretically, ectopic activity could be generated at any anatomical level proximal to those brain regions that mediate the sensory experience. Compelling evidence for peripheral neuropathic pain, however, points to substantial ectopic activity arising in primary sensory neurons. After peripheral nerve damage, spontaneous activity is generated at multiple sites, including in the neuroma (the site of injury with aborted axon growth), in the cell body of injured dorsal root ganglia (DRG) neurons (Amir et al. 2005), and in neighboring intact afferents (Wu et al. 2002). Spontaneous pain may arise both from ectopic activity in nociceptors (Bostock et al. 2005) and from low-threshold large myelinated afferents (Campbell et al. 1988) due to central sensitization and altered connectivity in the spinal cord (Woolf et al. 1992) (Figure 2). After spinal cord injury, spontaneous pain may result from increases in the intrinsic excitability of second-order neurons (Balasubramanyan et al. 2006, Hains \& Waxman 2007).

Voltage-gated sodium channels contribute largely to the generation of ectopic activity as indicated by the robust inhibitory effects of local anesthetics, which are nonselective sodium channel blockers (Sheets et al. 2008). DRG neurons express several sodium channels that are either sensitive or resistant to tetrodotoxin (TTX) (Fukuoka et al. 2008). However, which of these channels is responsible for the abnormal generation of action potentials is not entirely clear. Studies using gene knockdown with antisense oligonucleotides support a specific role for the Nav1.3 channel, which is upregulated in DRG neurons after nerve injury (Hains et al. 2003), but knockout of the channel fails to alter neuropathic pain-like behavior or ectopic activity (Nassar et al. 2006). On the other hand, preclinical models cannot directly measure 
spontaneous pain, a major failing that limits their utility as models of pain in patients. The TTX-resistant channel Nav1.8, which is predominantly expressed by nociceptors, does not support propagation of full-amplitude action potentials (Pinto et al. 2008) and instead modulates membrane excitability, particularly when phosphorylated (Hudmon et al. 2008). Experiments using Nav1.8 antisense and shRNA knockdown as well as pharmacological blockade with conotoxin and small-drug antagonists indicate a major role for this channel in generating neuropathic pain (Dong et al. 2007, Ekberg et al. 2006, Gold et al. 2003, Jarvis et al. 2007, Joshi et al. 2006, Roza et al. 2003). However, Nav1.8 knockout does not reduce the neuropathic pain phenotype (Nassar et al. 2005), low-dose TTX blocks the expression and development of neuropathic pain (Nieto et al. 2008), and Nav1.8 is markedly downregulated after axonal injury, producing a substantial reduction in TTX-R current densities (Berta et al. 2008). Although conditional deletion of Nav1.7 in nociceptors does not reduce neuropathic pain (Nassar et al. 2005), selective blockers for the channel display efficacy as antineuropathic agents (Hoyt et al. 2007, Schmalhofer et al. 2008). Global or conditional knockout of single ion channels does not appear to be a useful way to tease out their value as targets for analgesics because of compensation and redundancy.

The hyperpolarization-activated cyclic nucleotide-modulated channel (HCN), which contributes to the pacemaker current I(h), also generates ectopic activity in DRG neurons after nerve injury (Luo et al. 2007). Opening the neuronal potassium voltage-gated channel subfamily Q KCNQ, which is a mediator of the M current, selectively reduces activity in axotomized but not uninjured axons (Roza \& Lopez-Garcia 2008) and in human C-fiber axons (Lang et al. 2008), suggesting that this channel may be involved in regulating ectopic activity. Similarly, axotomy reduces calcium-activated potassium currents in DRG neurons, which will also result in increased membrane excitability (Sarantopoulos et al. 2007). There are likely several ectopic ion channel drivers that raise membrane excitability in different ways and in different neurons.

What triggers the changes in sensory neuron ion channel expression? An importin-dependent retrograde signal that involves RasGTPase (Yudin et al. 2008) activates massive transcriptional changes ( 2000 transcripts) in the soma of injured neurons, including altered regulation of ion channels (Costigan et al. 2002) and their accessory subunits (Pertin et al. 2005). It is likely that master switches such as the transcription factors Sox11, c-Jun, and ATF3 orchestrate these changes (Seijffers et al. 2007). Gene translation in axons appears to be important, both to signal the injury (Yudin et al. 2008) and to synthesize local effectors (Jimenez-Diaz et al. 2008). Neighboring uninjured neurons show fewer phenotypic changes than do injured ones (Decosterd et al. 2002), and these may be generated by signals from dennervated Schwann cells (Wu et al. 2002). Some of these signals, including cytokines and growth factors, may increase sodium and TRP channel currents in the axon and cell soma of neurons by posttranslational changes (Jin \& Gereau 2006, Zhu \& Oxford 2007).

Mice with a deletion of Cav2.2 (the N-type calcium channel) show reduced neuropathic painlike behavior (Saegusa et al. 2001). Intrathecal delivery of wconopeptide MVIIA, which blocks Cav2.2 in a non-use-dependent fashion, decreases neuropathic pain in preclinical models and patients, presumably by reducing transmitter release from nociceptors (McGivern 2006). The calcium channel auxiliary $\alpha 2 \delta 1$ subunit helps stabilize the poreforming $\alpha$ subunit of these channels in the membrane. Gabapentin and pregabalin, among the first-line treatments for neuropathic pain (Dworkin et al. 2007), bind to the $\alpha 2 \delta 1$ protein, interfere with the interaction between the auxiliary subunit and the $\alpha$ subunit, and impair membrane insertion of the channel (Hendrich et al. 2008). Both Cav2.2 and $\alpha 2 \delta$ subunits are upregulated in DRG neurons following nerve injury (McGivern 2006), which suggests that an N-type calcium channel complex may play a dominant role in pathological nociceptive signal transmission from the periphery. Different Cav2.2 splice forms, including one that is highly enriched in nociceptor 
neurons, constitute molecular switches for different nociceptor functions during neuropathic pain (Altier et al. 2007).

\section{Ectopic Transduction}

Enhanced sensitivity of injured sensory neurons to endogenous thermal and chemical stimuli may initiate spontaneous pain, whereas enhanced mechanical sensitivity can elicit dysesthesia or pain in response to tapping an injured nerve (Tinel's sign). Peripheral nerve axons exhibit sensory transduction capacities to noxious heat identical to their peripheral terminals in the skin, with the threshold characteristic of the noxious heat-sensitive TRPV1 channel $\left(41^{\circ} \mathrm{C}\right)$ (Hoffmann et al. 2008). Isolated peripheral nerves can also be sensitized to heat by intracellular signal transduction pathways (Fischer \& Reeh 2007). Therefore, normal body temperature may elicit spontaneous activity after nerve injury if the threshold of TRPV1 in axons were reduced to $38^{\circ} \mathrm{C}$ (Biggs et al. 2008). Knockdown of the channel with shRNA reduces neuropathic painlike behavior (Christoph et al. 2008).

\section{Central Sensitization}

Stimulus-evoked neuropathic pain could arise either as a result of peripheral sensitization of intact afferents (Fields et al. 1998) or from amplification within the CNS due to central sensitization (Woolf \& Salter 2000). Synaptic facilitation seems to predominate in most patients with peripheral neuropathic pain and in all patients with central neuropathic pain. It contributes to dynamic tactile allodynia as well as secondary hypersensitivity (Figure 2) (Campbell \& Meyer 2006). Presynaptic functional changes after peripheral nerve injury that increase synaptic strength include alterations in the synthesis of transmitters and neuromodulators (Obata et al. 2003) and in calcium channel density (Hendrich et al. 2008, Li et al. 2004). Postsynaptic changes involve phosphorylation of N-methyl-D-aspartate (NMDA) subunits (Ultenius et al. 2006) and increased receptor density due to trafficking and enhanced synthesis of ion channels and scaffold proteins (Cheng et al. 2008, Iwata et al. 2007, Miyabe et al. 2006, Takasusuki et al. 2007, Tao et al. 2003). Drugs that attenuate central sensitization by acting on calcium channel subunits to decrease transmitter release and on NMDA channels to reduce transmitter action (Chizh et al. 2007; Jorum et al. 2003) are effective treatment options in neuropathic pain (Dworkin et al. 2007). Although central sensitization was first described in the dorsal horn, similar synaptic changes occur in structures involved in the emotional aspects of pain such as the amygdala, anterior cingulate gyrus, and prefrontal cortex (Fu et al. 2008, Pedersen et al. 2007), and these may represent a substrate for long-term cognitive and mood changes that are learned and retained, for example, conditioned fear and addictive behavior.

Central sensitization is different from centralization, which hypothesizes that, after peripheral nerve injury, changes intrinsic to the CNS develop and maintain pain independent of any ongoing peripheral input (Devor 2006). These changes potentially include increased excitability (Balasubramanyan et al. 2006), structural alterations in synaptic circuitry (Woolf et al. 1992), degeneration of inhibitory interneurons (Scholz et al. 2005), and alterations in the brain stem regulation of nociceptive transmission (Vera-Portocarrero et al. 2006).

\section{Low-Threshold A $\beta$ Fiber-Mediated Pain}

Neuropathic pain involves a profound switch in sensitivity such that low-intensity input can generate pain, a disruption of the normal pattern of pain specificity (Perl 2007). The hypersensitivity occurs largely in the absence of peripheral sensitization; includes areas outside of injured nerve territories; is typically associated with a loss of C-fiber peripheral terminals, and sensitivity (Devigili et al. 2008); and disappears when conduction in large myelinated fibers is blocked (Campbell et al. 1988). Furthermore, ablation of the vast majority of nociceptor neurons does not alter the development and manifestation of neuropathic pain 
(Abrahamsen et al. 2008), whereas selective pharmacological blockade of large neurofilament-200-positive $\mathrm{A} \beta$ fibers abolishes dynamic tactile allodynia in nerve injury models (Yamamoto et al. 2008). The obvious conclusion from these data is that low-threshold $\mathrm{A} \beta$ fibers, which normally signal innocuous sensations, begin after neural lesions to produce pain (Khan et al. 2002; Witting et al. 2006). In keeping with this finding, loss of the PKC $\gamma$ interneurons in the most ventral part of the superficial dorsal horn (lamina IIi) that are driven only by $A \beta$ fiber innocuous input (Neumann et al. 2008) leads to reduced neuropathic but preserved nociceptive pain (Malmberg et al. 1997). Furthermore, after nerve injury polysynaptic and monosynaptic $A \beta$ fiber input to neurons increases in the most superficial laminae of the dorsal horn (Okamoto et al. 2001), an area that normally only receives input from A $\delta$ and C fibers (Lu \& Perl 2005). Although noxious stimuli activate ERK MAP kinase in superficial dorsal horn neurons in noninjured animals (Ji et al. 1999), after peripheral nerve injury A $\beta$ fiber stimulation acquires this capacity (Matsumoto et al. 2008). Tactile stimulation also begins to induce c-Fos in these nociceptive neurons (Bester et al. 2000). Somehow, as a consequence of peripheral nerve injury, low-threshold input from large myelinated fibers is transferred from nonnociceptive to nociceptive circuits in the spinal cord. How does this plasticity occur?

\section{Disinhibition}

A number of changes either independently or together can promote $A \beta$ fiber-mediated pain: central sensitization, disinhibition, and central afferent terminal sprouting. Inhibitory dorsal horn interneurons synapse with the central terminals of primary sensory neurons and presynaptically modulate afferent input. Spinal interneurons also regulate activity in postsynaptic transmission neurons through GABAergic and glycinergic inhibition. Pharmacological removal of GABAergic or glycinergic control provokes tactile allodynia (Thompson et al. 1993) and increases synaptic currents from A $\beta$ fibers to nociceptive lamina I neurons (Baba et al. 2003, Miraucourt et al. 2007, Torsney \& MacDermott 2006).

Descending pathways that modulate the spinal transmission of nociceptive input originate in the anterior cingulate gyrus, amygdala, and hypothalamus and are relayed to the spinal cord through brain stem nuclei in the periaqueductal gray and rostroventral medulla. The inhibitory transmitters in these pathways include norepinephrine, 5-hydroxytryptamine, and endogenous opioids. After nerve injury, this intricate system of inhibitory control shifts. Tonic noradrenergic inhibition that acts on $\alpha 2$-adrenoceptors appears to be suspended (Rahman et al. 2008), and the net effect of descending serotoninergic input changes from inhibition to facilitation (Bee \& Dickenson 2008, Vera-Portocarrero et al. 2006). Amine uptake inhibitors like the tricylic antidepressants or serotonin norepinephrine reuptake inhibitors (SNRIs) boost endogenous inhibition by increasing the levels of norepinephrine (Matsuzawa-Yanagida et al. 2008).

Following nerve injury, primary afferents reduce their expression of $\mu$ opioid receptors, and dorsal horn neurons are less sensitive to inhibition by $\mu$ opioid agonists (Kohno et al. 2005). Furthermore, several different mechanisms contribute to a loss of pre- and postsynaptic GABAergic inhibition in the spinal cord. In nociceptive lamina I neurons, the transmembrane gradient for chloride ions changes after nerve injury so that activation of $\mathrm{GABA}_{\mathrm{A}}$ receptors no longer leads to hyperpolarization. Instead, it may induce depolarization, provoking paradoxical excitation and spontaneous activity (Keller et al. 2007). BDNF released from active microglia causes this disturbance by inducing a downregulation of the potassium chloride cotransporter isoform 2 (Coull et al. 2005). Independently, inhibition in the superficial dorsal horn of the spinal cord is compromised by a loss of GABAergic interneurons (Scholz et al. 2005), reducing afferent stimulation-evoked GABAergic inhibitory postsynaptic currents (IPSCs) (Moore et al. 2002). Preventing apoptotic cell death fully restores GABAergic IPSCs and attenuates 
mechanical allodynia, hyperalgesia, and cold allodynia after nerve injury (Scholz et al. 2005). Loss of spinal inhibitory interneurons may contribute to the persistence of neuropathic pain, although pain-like behavior after sciatic nerve injury in the absence of neuronal cell death has been reported (Polgar et al. 2005). Despite the apparent role of GABAergic disinhibition in neuropathic pain, $\mathrm{GABA}_{\mathrm{A}}$ receptor modulators such as benzodiazepines or $\mathrm{GABA}_{\mathrm{B}}$ receptor agonists are rarely used to treat neuropathic pain because they have a narrow therapeutic window. Specific GABA agonists that bind to the $\alpha_{2}$ or $\alpha_{3}$ but not $\alpha_{1}$ subunits of spinal $\mathrm{GABA}_{\mathrm{A}}$ receptors may allow analgesia without sedation or motor impairment (Knabl et al. 2008).

\section{Structural Changes}

Peripheral axonal injury prompts sensory neurons into an actively growing state by increasing the expression of regeneration-associated genes (Costigan et al. 2002). This peripheral sprouting aids the reconnection of damaged peripheral axons with their targets. However, increasing the intrinsic capacity to grow can also lead to a sprouting of the central axon terminals of injured neurons in the spinal cord (Woolf et al. 1992). Large myelinated A $\beta$ fibers normally terminate in the ventral laminae of the dorsal horn (lamine III-V), whereas thinly myelinated $\mathrm{A} \delta$ fibers and unmyelinated $\mathrm{C}$-fiber nociceptors terminate in the superficial laminae (I and II). Following peripheral nerve injury, bulk-labeling, single afferent filling, and A fiber marker experiments all suggest that A $\beta$ fibers sprout into lamina II (Kohama et al. 2000; Soares et al. 2002, 2007; Watanabe et al. 2007; Woolf et al. 1992). However, these findings remain controversial because some of the labeling techniques lack specificity, and some uninjured Afibers are present in lamina II in some species (Bao et al. 2002, Woodbury et al. 2008).

Nevertheless, these structural changes, if they do occur, may be an anatomical substrate for the entry of low-threshold $A \beta$ fiber input into nociceptive pathways after nerve injury.

\section{Neurodegeneration and Chronic Pain}

Both primary sensory and dorsal horn neurons die after peripheral nerve injury. Primary afferents degenerate after transection of their peripheral axons, with a much greater loss of small-diameter neurons, including nociceptors, than large myelinated neurons (Okamoto et al. 2001, Tandrup et al. 2000). A loss of $20 \%$ of superficial dorsal horn neurons occurs after partial peripheral nerve injury. The degeneration of spinal neurons occurs protracted over several weeks and is most likely a consequence of sustained ectopic activity of primary sensory afferents and glutamate-mediated excitotoxicity (Scholz et al. 2005). Magnetic resonance imaging (MRI) investigations in patients with chronic neuropathic pain hint that neurodegeneration may also occur in the brain. Voxel-based morphometry shows decreases in gray matter volume and density in MRIs of the brain of patients with chronic back pain, phantom pain, migraine, tension-type headache, and fibromyalgia, although with varying degree and regional distribution (May 2008). The nature of these structural changes remains to be determined, as well as whether neurodegeneration is a cause and if analgesic treatment can prevent the changes. These findings raise the possibility that neuropathic pain may have elements that resemble neurodegenerative diseases and requires neuroprotective treatment strategies.

\section{Neuro-Immune Interactions}

In the PNS, immune surveillance is performed by macrophages, which identify and clear cellular debris and present surface antigens to activate T-lymphoctyes. Both macrophages and T-lymphocytes communicate via cytokines and chemokines with neurons, Schwann cells, and DRG satellite cells. Macrophage activation is a central component of the Wallerian degeneration distal to axonal injury, and immune activation in the injured nerve and DRG appears to contribute to pain hypersensitivity (Scholz \& Woolf 2007). Microglia, the 
macrophages of the CNS, are massively activated in the dorsal horn soon after peripheral nerve injury. Microglial activation occurs in a topographically organized fashion close to the central terminals of injured afferents (Beggs \& Salter 2007, Scholz et al. 2008), and microglial cells release many immune modulators that contribute to the induction and maintenance of neuropathic pain by altering neuronal function (Saab et al. 2008, Suter et al. 2007) (Table 1). Fractalkine (CX3CL1), for example, is expressed by neurons and astrocytes, whereas its receptor CX3CR3 is expressed on microglia, suggesting a signaling role by the chemokine between these cells (Milligan et al. 2008). CCL2 (MCP-1) and its receptor CCR2 are both upregulated in the DRG and distributed to the spinal cord after nerve injury (White et al. 2007). Intrathecal administration of CX3CL1 or CCL2 produces pain in naiive animals, while their neutralization prevents neuropathic pain hypersensitivity (Abbadie 2005, Watkins et al. 2007).

Signaling molecules that act on microglia in the spinal cord after nerve injury include ATP, which through activation of P2X4 and P2X7 receptors (Inoue 2006, Inoue et al. 2007, Trang et al. 2006) leads to BDNF release and IL1 $\beta$ synthesis, respectively. Microglia both produce and are a target of the $\mathrm{C} 5 \mathrm{a}$ anaphylatoxin peptide, a member of the complement system (Griffin et al. 2007, Mika 2008). The Toll-like receptors TLR-2, TLR-3 and TLR-4 are also critically involved in immune-mediated pain signaling in the dorsal horn (DeLeo et al. 2004, Guo \& Schluesener 2007, Obata et al. 2008). Microglial responses to nerve injury are characterized by activating p38MAP kinase, extracellular signal-related kinase (ERK), and Src-family kinases (Ji \& Suter 2007). Another example for neuron-glia interactions contributing to neuropathic pain are the matrix metalloproteinases MMP2 and MMP9. They are produced by both neurons and glia and mediate pain hypersensitivity by initiating IL1 $\beta$ cleavage and microglial and astrocytic activation (Kawasaki et al. 2008). Inhibition of immune function represents a major avenue for therapeutic intervention for neuropathic pain (Table 1).

\section{Seeing Pain in Patients}

Preclinical research focuses largely on single molecules, changes in particular neurons or defined circuits, and how they contribute to behavioral alterations that are considered surrogates of neuropathic pain. Functional magnetic resonance imaging (FMRI) use enables blood oxygen level dependent (BOLD) signals to detect changes in cerebral activity in patients with neuropathic pain, and this technique allows the study of discriminative sensory, emotional, motivational, and modulatory responses in particular regions of the brain and brain stem (May 2007,Tracey 2008, Tracey \& Mantyh 2007). The reorganization of the somatosensory cortex after peripheral nerve lesions reveals the plasticity of the brain (Flor 2003). Patients with chronic pain show strong activation of the prefrontal cortex, the same area that shows reduction in gray matter density (Baliki et al. 2008), as well as disruption in resting functional connectivity of widespread cortical areas (Baliki et al. 2008). Imaging studies provide an opportunity to obtain objective measures of subjective sensations to identify which areas of the brain are likely involved in the processing of neuropathic pain and to evaluate the location and mechanisms of treatment effects (Becerra et al. 2006).

\section{THE NEUROPATHIC PAIN PHENOTYPE}

\section{Animal Surrogate Models}

Many rodent models of neuropathic pain have been developed (Table 2). Some have been designed to mimic human diseases, others to explore pathophysiological mechanisms in the nervous system, and some as a convenient means to screen for putative analgesics. Although these models collectively have great utility in exploring the maladaptive plasticity induced by neural damage, they are generally less useful as direct surrogates of pain phenotypes in patients and, by themselves, not always good predictors of the involvement of particular targets or 
processes in human neuropathic pain. How distinct forms of neural damage activate different sets of changes in the nociceptive system, particularly over a time course that is relevant to the transition from acute to chronic pain, and how these changes engage different outcome measures need to be carefully explored. Reflexive changes in the thresholds to defined stimuli, complex behaviors that capture sensory and mood disturbances, and alterations in operant behavior or choice paradigms that may reflect spontaneous pain also need to be investigated further. We still do not have enough insight into which specifically painrelated mechanisms in the nervous system are responsible for behavioral outcome measures in animals. Because subjective symptoms cannot be evaluated, the representation of neuropathic pain in animal models is necessarily incomplete and the human experience of pain too complex to be fully reproduced.

Outcome measures in rodent models rely on motor activity, such as withdrawal or reduced weight bearing, and therefore locomotor as well as sensory function are assayed (Vierck et al. 2008). Nevertheless, tactile allodynia in rodent models appears to correspond with neuropathic mechanical hypersensitivity in patients (Koltzenburg et al. 1994, Rowbotham \& Fields 1996). Pharmacological studies show that effective analgesic drugs for human neuropathic pain (gabapentin, morphine, fluoxetine) but not ineffective ones (indomethacin) also reduce rodent tactile allodynia (LaBuda \& Little 2005). Furthermore, heat hyperalgesia and tactile sensitivity do not correlate in mice (Mogil et al. 1999b) or in humans (Koltzenburg et al. 1994, Rowbotham \& Fields 1996).

\section{Lost in Translation}

Treating neuropathic pain in patients remains a major challenge because relief is only partial in most patients, and responders to treatment cannot be identified. One reason for the lack of clinical improvement is the inability to determine active pain mechanisms in patients.

Quantitative sensory testing and electrophysiological investigations such as nerve conduction studies or evoked potentials, though they reveal information on the function of different types of sensory nerve fibers, do not provide insight into the cellular and molecular processes responsible for the pain (Hansson et al. 2007). Functional imaging reveals abnormal processing of sensory input in patients but is limited to research studies (Tracey \& Mantyh 2007). Skin biopsies document sensory fiber loss as an indicator of deafferentation; however, they are invasive and not suitable for routine clinical practice. These difficulties have prevented the establishment of mechanism-based classifications of neuropathic pain and the development of treatment strategies targeted at particular mechanisms (Figure 4).

\section{Subtypes of Clinical Neuropathic Pain}

Diagnostic labels for neuropathic pain conditions are usually based on anatomy, as for example in small fiber neuropathy or radicular low back pain, or etiology, as in postherpetic neuralgia or diabetic polyneuropathy. They designate the underlying lesion or disease of the nervous system without revealing features of the pain that may reflect the mechanisms responsible. Conditions associated with neuropathic pain produce a variety of symptoms and signs, some of which correlate closely with a particular disease, such as tic douloureux in trigeminal neuralgia. More often, however, symptoms and signs overlap across diagnostic entities, indicating both that some mechanisms responsible for the manifestation of pain-related symptoms and signs may be common among different conditions and that different mechanisms may produce a similar outcome.

To develop a successful targeted approach to pain management, it will be important to determine, for example, if a patient is suffering from spontaneous or evoked pain, which mechanisms are causing the pain, and how these mechanisms respond to drugs with different mechanisms of actions. Instead, crude rating scales of global pain intensity are usually 
employed in clinical practice and research trials to measure pain and the efficacy of analgesic drugs. Pain assessment often constitutes an evaluation of sensory pain qualities, the affective response to pain, and physical and psychosocial functioning, but none of these parameters reveals neurobiological features of pain that can be targeted by treatment interventions.

Treatment recommendations for neuropathic pain are issued for particular conditions defined by disease etiology (Finnerup et al. 2005), despite the fact that the etiological cause of neural damage is not equivalent to the neurobiological mechanisms responsible for persisting pain. Assuming that all forms of neuropathic pain are similar, evidence of analgesic efficacy in one disease is often applied to neuropathic pain in general (Finnerup et al. 2005). As a consequence, algorithms designed to determine the best analgesic treatment for an individual patient focus on comorbidities and associated risks of adverse effects and not on the nature or phenotype of pain (Dworkin et al. 2007). Given the inability to identify pain mechanisms in patients, a standardized and comprehensive classification of pain phenotypes may provide the next best approach to capture relevant information that may indirectly reflect pain mechanisms. To define such subtypes of pain, it would be necessary to comprehensively examine constellations of pain-related symptoms and signs and reveal distinct and reliable patterns of association.

Single symptoms or signs are not suitable because they may be caused by different mechanisms; for example, mechanical allodynia is observed in models of peripheral or central sensitization reduced inhibitory control in the spinal cord or after microglial activation in the dorsal horn. A standardized assessment of symptoms and signs would allow investigators to test the effects of analgesic drugs on unique features of particular pain subtypes and thus improve the translation of preclinical findings (Joshi et al. 2006). This information might help predict treatment response in individual patients by matching their pain profiles with established pain subtypes that are known to respond to certain treatments (Figure 4).

\section{GENETIC DETERMINANTS OF NEUROPATHIC PAIN}

Genetic variants that alter the risk of developing neuropathic pain and the degree of its severity offer an opportunity for investigators to define molecular mechanisms; they may also provide diagnostic tools and targets for treatment. Two general strategies are possible for human genetic studies: identifying rare mutations with large effects that produce distinct genetic diseases, or studying common genetic variants with smaller effects in large patient cohorts. Inbred mouse strains can be used to establish the extent to which neuropathic pain-like behavior is heritable, whereas expression profiling and mutation studies can identify those genes that affect the pain phenotype, and by which mechanism. Analysis of analgesic targets can also identify genetic modulators of neuropathic pain (Table 3).

\section{Pain Heritability}

Because many causes of neural damage associated with neuropathic pain are sporadic, it is rarely possible to rely on family history and classic genetic techniques to evaluate the degree to which a heritable susceptibility for developing the pain is involved. However, two recent twin studies using experimental (nociceptive) pain models in healthy volunteers have estimated the impact of inherited heritability of pain sensitivity with a broad range 20\%-60\% (Nielsen et al. 2008, Norbury et al. 2007), the significance of which is difficult to interpret. A study using 11 inbred mice strains tested with 12 different pain measures revealed heritability between 30\% and 76\% (Mogil et al. 1999a). With respect to pain-like behavior following nerve injury, three measures were recorded: the paw withdrawal threshold for mechanical stimuli, the thermal pain threshold (latency of response), and autotomy (scratching and biting of the denervated hindpaw). These behaviors gave heritability estimates of $45 \%, 45 \%$, and $63 \%$, respectively, and suggest that the neuropathic pain phenotype varies widely in outbred rodent strains, as it does in patients. 


\section{Genetic Risk of Developing Neuropathic Pain}

In humans, the genetic risk of developing neuropathic pain after neural injury, its extent, presentation, and duration are very likely to result from multiple risk-conferring genes. Casecontrol studies using whole-genome analysis or candidate gene association studies can be conducted to identify these genes. Association studies compare allele frequencies between unrelated subjects with and without a particular trait to identify DNA regions correlated with the trait. Alleles are DNA codes at a given position on the genome that constitute markers of coinherited regions of DNA known as haplotype blocks. A haplotype block significantly coinherited with a trait is a strong indication that the DNA contains a version of a gene that in some way modifies the carriers' phenotype to create the trait.

Candidate gene association studies have preliminarly identified polymorphisms in catecholO-methyltransferase (COMT) that modulate nociceptive and dysfunctional (temporomandibular joint disorder) pain (Diatchenko et al. 2005, Nackley et al. 2006). COMT is an enzyme in the metabolism cascade for dopamine, norepinephrine, and epinephrine. Higher COMT activity leads to lower transmitter and pain levels (Diatchenko et al. 2007). Other such association studies have linked polymorphisms in the $\mu$-opioid receptor 1 (OPRM1) to morphine sensitivity (Lotsch \& Geisslinger 2007) and in the melanocortin-1 receptor (MCR1) to $\kappa$-opioid-induced analgesia in females (Mogil et al. 2003).

No whole-genome association study has been conducted yet for neuropathic pain. The problems are formidable: how to phenotype patients in a standardized way to eliminate spurious associations, which controls to use, and how large the cohorts need to be to retain sensitivity but eliminate false positive results that may arise from multiple testing. An estimated 2000-5000 patients and controls would be required for studies assaying 1 million SNPs at a significance level of $<10^{-7}$ (Wellcome-Consortium 2007). Potential whole-genome association studies include comparisons of patients who do and do not develop neuropathic pain after iatrogenic nerve injury and diabetic patients with peripheral neuropathy with and without pain. Another method is to use experimental methods to identify potential gene targets that can then be tested in smaller cohorts for association. This approach has led to the identification of a haplotype in the enzyme GTP cyclohydrolase 1 (GCH1) that reduces the risk of persistent radicular back pain after discectomy (Tegeder et al. 2006). This GCH1 haplotype has a population frequency of $15.4 \%$ ( $\sim 2 \%-3 \%$ of individuals have two copies and $20 \%$ have one copy), and homozygous carriers display lower experimental pain thresholds than do individuals with no copy (Tegeder et al. 2006, 2008). White blood cells from individuals with the haplotype have normal basal BH4 levels, but GCH1 activity fails to increase in response to a stress challenge (Tegeder et al. 2006).

GCH1 was identified in a study using expression profiles to identify genes regulated in the DRG of rats after peripheral nerve injury (Tegeder et al. 2006). Analysis of three distinct nerve injury models consistently indicated de novo expression of enzymes involved in the synthesis and recycling of tetrahydrobiopterin (BH4). $\mathrm{BH} 4$ is an essential cofactor for aromatic amine hydroxylases that synthesize serotonin and catecholamines and for all nitric oxide synthases (Tegeder et al. 2006) (Figure 5). Increased BH4 synthesis in the injured DRG contributes to increase nitric oxide release and produces a large calcium flux in DRG neurons. GCH1 is the rate-limiting enzyme for the synthesis of $\mathrm{BH} 4$, and inhibition of $\mathrm{GCH} 1$ produces analgesia in rodent models of neuropathic pain. These findings demonstrate the validity of translational pain research and the power of studying neuropathic pain in parallel in preclinical and clinical models. 


\section{SUMMARY POINTS}

1. Neural damage to either the PNS or CNS provokes maladaptive responses in nociceptive pathways that drive spontaneous pain and sensory amplification. This maladaptive plasticity leads to persistent changes and, therefore, needs to be considered a disease state of the nervous system in its own right, independent of the etiological factor that triggered it.

2. Multiple mechanisms are responsible for neuropathic pain. In the PNS, they include altered gene expression and changes in ion channels that lead to ectopic activity. In the CNS, the regulation of many genes also changes. In addition, synaptic facilitation and loss of inhibition at multiple levels of the neuraxis produce central amplification. Neuronal cell death and aberrant synaptic connectivity provide the structural basis for persistently altered processing of both nociceptive and innocuous afferent input.

3. Neural damage provokes vigorous and highly organized neuroimmune interactions that play a key role in initiating many cellular mechanisms that underlie persistent neuropathic pain.

4. Genetically determined susceptibility is likely to combine with the environment to determine the risk of developing neuropathic pain.

5. Given the complexity of numerous intertwined genetic, cellular, and molecular components that cause neuropathic pain, clinical classifications need to incorporate multiple aspects of the pain phenotype to guide the identification of underlying mechanisms and help assess the likelihood of response to treatment.

\section{FUTURE ISSUES}

1. Will selective sensory neuron-specific sodium channel blockers have utility in peripherally derived neuropathic pain?

2. The utility of preclinical models of neuropathic pain, for candidate gene identification and validation, pain mechanisms definition, and the investigation of treatment interventions need to be critically evaluated.

3. Will it be possible to reveal mechanisms of neuropathic pain in humans?

4. Will a mechanism-based clinical approach lead to improvements in diagnosis and treatment?

5. Will disease-modifying therapy prevent the development of neuropathic pain?

6. Once established, can neuropathic pain ever be reversed?

7. Will genes identified by expression profiling and SNP association studies provide targets for novel analgesics and biomarkers of neuropathic pain?

8. Whole genome association studies in carefully phenotyped cohorts are needed to identify genetic contributions to the risk of developing neuropathic pain.

\section{Acknowledgments}

We thank the NIH for support. 


\section{Glossary}

Neuropathic pain, maladaptive plasticity caused by a lesion or disease affecting the somatosensory system. Alters nociceptive signal processing so that pain is felt in the absence of a stimulus, and responses to innocuous and noxious stimuli are enhanced

Dysfunctional pain, amplification of nociceptive signaling in the absence of either inflammation or neural lesions

Nociceptive pain, physiological pain produced by noxious stimuli that activate high-threshold nociceptor neurons

CNS, central nervous system

TRP, transient receptor potential

Inflammatory pain, pain hypersensitivity due to peripheral tissue inflammation involving the detection of active inflammation by nociceptors and a sensitization of the nociceptive system PNS, peripheral nervous system

DRG, dorsal root ganglion

Central sensitization, an increase in synaptic strength in nociceptive circuits that results from synaptic facilitation or a reduction in inhibition

Peripheral sensitization, an increase in the sensitivity of the peripheral terminals of nociceptors due to a decrease in transduction threshold and an increase in membrane excitability

Allodynia, a painful response to a usually innocuous stimulus

Secondary hypersensitivity, pain from normal peripheral sensory inputs outside inflamed tissue due to plasticity (sensitization) within the CNS

NMDA, N-methyl-D-aspartate

GABA, gamma amino butyric acid

Hyperalgesia, a heightened response to a noxious stimulus

\section{LITERATURE CITED}

Abbadie C. Chemokines, chemokine receptors and pain. Trends Immunol 2005;26:529-34. [PubMed: 16099720]

Abrahamsen B, Zhao J, Asante CO, Cendan CM, Marsh S, et al. The cell and molecular basis of mechanical, cold, and inflammatory pain. Science 2008;321:702-5. [PubMed: 18669863]

Altier C, Dale CS, Kisilevsky AE, Chapman K, Castiglioni AJ, et al. Differential role of N-type calcium channel splice isoforms in pain. J. Neurosci 2007;27:6363-73. [PubMed: 17567797]

Amir R, Kocsis JD, Devor M. Multiple interacting sites of ectopic spike electrogenesis in primary sensory neurons. J. Neurosci 2005;25:2576-85. [PubMed: 15758167]

Anand P, Birch R. Restoration of sensory function and lack of long-term chronic pain syndromes after brachial plexus injury in human neonates. Brain 2002;125:113-22. [PubMed: 11834597]

Baba H, Ji RR, Kohno T, Moore KA, Ataka T, et al. Removal of GABAergic inhibition facilitates polysynaptic A fiber-mediated excitatory transmission to the superficial spinal dorsal horn. Mol. Cell Neurosci 2003;24:818-30. [PubMed: 14664828]

Balasubramanyan S, Stemkowski PL, Stebbing MJ, Smith PA. Sciatic chronic constriction injury produces cell-type-specific changes in the electrophysiological properties of rat substantia gelatinosa neurons. J. Neurophysiol 2006;96:579-90. [PubMed: 16611846]

Baliki MN, Geha PY, Apkarian AV, Chialvo DR. Beyond feeling: chronic pain hurts the brain, disrupting the default-mode network dynamics. J. Neurosci 2008;28:1398-403. [PubMed: 18256259]

Bao L, Wang HF, Cai HJ, Tong YG, Jin SX, et al. Peripheral axotomy induces only very limited sprouting of coarse myelinated afferents into inner lamina II of rat spinal cord. Eur. J. Neurosci 2002;16:17585. [PubMed: 12169100]

Becerra L, Morris S, Bazes S, Gostic R, Sherman S, et al. Trigeminal neuropathic pain alters responses in CNS circuits to mechanical (brush) and thermal (cold and heat) stimuli. J. Neurosci 2006;26:10646-57. [PubMed: 17050704] 
Bee LA, Dickenson AH. Descending facilitation from the brainstem determines behavioural and neuronal hypersensitivity following nerve injury and efficacy of pregabalin. Pain 2008;140(1):209-23. [PubMed: 18809257]

Beggs S, Salter MW. Stereological and somatotopic analysis of the spinal microglial response to peripheral nerve injury. Brain Behav. Immun 2007;21:624-33. [PubMed: 17267172]

Benn SC, Woolf CJ. Adult neuron survival strategies—slamming on the brakes. Nat. Rev. Neurosci 2004;5:686-700. [PubMed: 15322527]

Bennett GJ, Xie YK. A peripheral mononeuropathy in rat that produces disorders of pain sensation like those seen in man. Pain 1988;33:87-107. [PubMed: 2837713]

Berta T, Poirot O, Pertin M, Ji RR, Kellenberger S, Decosterd I. Transcriptional and functional profiles of voltage-gated $\mathrm{Na}(+)$ channels in injured and non-injured DRG neurons in the SNI model of neuropathic pain. Mol. Cell Neurosci 2008;37:196-208. [PubMed: 17964804]

Bester H, Beggs S, Woolf CJ. Changes in tactile stimuli-induced behavior and c-Fos expression in the superficial dorsal horn and in parabrachial nuclei after sciatic nerve crush. J. Comp. Neurol 2000;428:45-61. [PubMed: 11058224]

Biggs JE, Yates JM, Loescher AR, Clayton NM, Robinson PP, Boissonade FM. Effect of SB-750364, a specific TRPV1 receptor antagonist, on injury-induced ectopic discharge in the lingual nerve. Neurosci. Lett 2008;443(1):41-45. [PubMed: 18634850]

Binshtok AM, Wang H, Zimmermann K, Amaya F, Vardeh D, et al. Nociceptors are interleukin-1 $\beta$ sensors. J. Neurosci. 2008In press

Bostock H, Campero M, Serra J, Ochoa JL. Temperature-dependent double spikes in C-nociceptors of neuropathic pain patients. Brain 2005;128:2154-63. [PubMed: 15947060]

Bouhassira D, Lanteri-Minet M, Attal N, Laurent B, Touboul C. Prevalence of chronic pain with neuropathic characteristics in the general population. Pain 2008;136:380-87. [PubMed: 17888574]

Cafferty WB, McGee AW, Strittmatter SM. Axonal growth therapeutics: regeneration or sprouting or plasticity? Trends Neurosci 2008;31:215-20. [PubMed: 18395807]

Campbell JN, Meyer RA. Mechanisms of neuropathic pain. Neuron 2006;52:77-92. [PubMed: 17015228]

Campbell JN, Raja SN, Meyer RA, Mackinnon SE. Myelinated afferents signal the hyperalgesia associated with nerve injury. Pain 1988;32:89-94. [PubMed: 3340426]

Chacur M, Milligan ED, Gazda LS, Armstrong C, Wang H, et al. A new model of sciatic inflammatory neuritis (SIN): induction of unilateral and bilateral mechanical allodynia following acute unilateral perisciatic immune activation in rats. Pain 2001;94:231-44. [PubMed: 11731060]

Cheng HT, Suzuki M, Hegarty DM, Xu Q, Weyerbacher AR, et al. Inflammatory pain-induced signaling events following a conditional deletion of the N-methyl-d-aspartate receptor in spinal cord dorsal horn. Neuroscience 2008;155(3):948-58. [PubMed: 18621103]

Chizh BA, Gohring M, Troster A, Quartey GK, Schmelz M, Koppert W. Effects of oral pregabalin and aprepitant on pain and central sensitization in the electrical hyperalgesia model in human volunteers. Br. J. Anaesth 2007;98:246-54. [PubMed: 17251214]

Christoph T, Bahrenberg G, De Vry J, Englberger W, Erdmann VA, et al. Investigation of TRPV1 lossof-function phenotypes in transgenic shRNA expressing and knockout mice. Mol. Cell Neurosci 2008;37:579-89. [PubMed: 18249134]

Costigan M, Befort K, Karchewski L, Griffin RS, D’Urso D, et al. Replicate high-density rat genome oligonucleotide microarrays reveal hundreds of regulated genes in the dorsal root ganglion after peripheral nerve injury. BMC Neurosci 2002;3:16. [PubMed: 12401135]

Coull JA, Beggs S, Boudreau D, Boivin D, Tsuda M, et al. BDNF from microglia causes the shift in neuronal anion gradient underlying neuropathic pain. Nature 2005;438:1017-21. [PubMed: 16355225]

Cox JJ, Reimann F, Nicholas AK, Thornton G, Roberts E, et al. An SCN9A channelopathy causes congenital inability to experience pain. Nature 2006;444:894-98. [PubMed: 17167479]

Crown ED, Gwak YS, Ye Z, Johnson KM, Hulsebosch CE. Activation of p38 MAP kinase is involved in central neuropathic pain following spinal cord injury. Exp. Neurol 2008;213(2):257-67. [PubMed: 18590729] 
Decosterd I, Ji RR, Abdi S, Tate S, Woolf CJ. The pattern of expression of the voltage-gated sodium channels $\mathrm{Na}(\mathrm{v}) 1.8$ and $\mathrm{Na}(\mathrm{v}) 1.9$ does not change in uninjured primary sensory neurons in experimental neuropathic pain models. Pain 2002;96:269-77. [PubMed: 11972999]

Decosterd I, Woolf CJ. Spared nerve injury: an animal model of persistent peripheral neuropathic pain. Pain 2000;87:149-58. [PubMed: 10924808]

DeLeo JA, Tanga FY, Tawfik VL. Neuroimmune activation and neuroinflammation in chronic pain and opioid tolerance/hyperalgesia. Neuroscientist 2004;10:40-52. [PubMed: 14987447]

Detloff MR, Fisher LC, McGaughy V, Longbrake EE, Popovich PG, Basso DM. Remote activation of microglia and pro-inflammatory cytokines predict the onset and severity of below-level neuropathic pain after spinal cord injury in rats. Exp. Neurol 2008;212:337-47. [PubMed: 18511041]

Devigili G, Tugnoli V, Penza P, Camozzi F, Lombardi R, et al. The diagnostic criteria for small fibre neuropathy: from symptoms to neuropathology. Brain 2008;131:1912-25. [PubMed: 18524793]

Devor M. Centralization, central sensitization and neuropathic pain. Focus on "sciatic chronic constriction injury produces cell-type-specific changes in the electrophysiological properties of rat substantia gelatinosa neurons.”. J. Neurophysiol 2006;96:522-23. [PubMed: 16835360]

Dhaka A, Viswanath V, Patapoutian A. TRP ion channels and temperature sensation. Annu. Rev. Neurosci 2006;29:135-61. [PubMed: 16776582]

Diatchenko L, Nackley AG, Tchivileva IE, Shabalina SA, Maixner W. Genetic architecture of human pain perception. Trends Genet 2007;23:605-13. [PubMed: 18023497]

Diatchenko L, Slade GD, Nackley AG, Bhalang K, Sigurdsson A, et al. Genetic basis for individual variations in pain perception and the development of a chronic pain condition. Hum. Mol. Genet 2005;14:135-43. [PubMed: 15537663]

Dieleman JP, Kerklaan J, Huygen FJ, Bouma PA, Sturkenboom MC. Incidence rates and treatment of neuropathic pain conditions in the general population. Pain 2008;137:681-88. [PubMed: 18439759]

Dong XW, Goregoaker S, Engler H, Zhou X, Mark L, et al. Small interfering RNA-mediated selective knockdown of $\mathrm{Na}(\mathrm{V}) 1.8$ tetrodotoxin-resistant sodium channel reverses mechanical allodynia in neuropathic rats. Neuroscience 2007;146:812-21. [PubMed: 17367951]

Drenth JP, Waxman SG. Mutations in sodium-channel gene SCN9A cause a spectrum of human genetic pain disorders. J. Clin. Invest 2007;117:3603-9. [PubMed: 18060017]

Ducreux D, Attal N, Parker F, Bouhassira D. Mechanisms of central neuropathic pain: a combined psychophysical and fMRI study in syringomyelia. Brain 2006;129:963-76. [PubMed: 16434417]

Dworkin RH, Backonja M, Rowbotham MC, Allen RR, Argoff CR, et al. Advances in neuropathic pain: diagnosis, mechanisms, and treatment recommendations. Arch. Neurol 2003;60:1524-34. [PubMed: 14623723]

Dworkin RH, O'Connor AB, Backonja M, Farrar JT, Finnerup NB, et al. Pharmacologic management of neuropathic pain: evidence-based recommendations. Pain 2007;132:237-51. [PubMed: 17920770]

Ekberg J, Jayamanne A, Vaughan CW, Aslan S, Thomas L, et al. muO-conotoxin MrVIB selectively blocks Nav1.8 sensory neuron specific sodium channels and chronic pain behavior without motor deficits. Proc. Natl. Acad. Sci. USA 2006;103:17030-35. [PubMed: 17077153]

Fields HL, Rowbotham M, Baron R. Postherpetic neuralgia: irritable nociceptors and deafferentation. Neurobiol. Dis 1998;5:209-27. [PubMed: 9848092]

Finnerup NB, Otto M, McQuay HJ, Jensen TS, Sindrup SH. Algorithm for neuropathic pain treatment: an evidence based proposal. Pain 2005;118:289-305. [PubMed: 16213659]

Finnerup NB, Sindrup SH, Jensen TS. Chronic neuropathic pain: mechanisms, drug targets and measurement. Fundam. Clin. Pharmacol 2007a;21:129-36. [PubMed: 17391285]

Finnerup NB, Sorensen L, Biering-Sorensen F, Johannesen IL, Jensen TS. Segmental hypersensitivity and spinothalamic function in spinal cord injury pain. Exp. Neurol 2007b;207:139-49. [PubMed: 17628539]

Fischer MJ, Reeh PW. Sensitization to heat through G-protein-coupled receptor pathways in the isolated sciatic mouse nerve. Eur. J. Neurosci 2007;25:3570-75. [PubMed: 17610576]

Flor H. Remapping somatosensory cortex after injury. Adv. Neurol 2003;93:195-204. [PubMed: 12894409] 
Fu Y, Han J, Ishola T, Scerbo M, Adwanikar H, et al. PKA and ERK, but not PKC, in the amygdala contribute to pain-related synaptic plasticity and behavior. Mol. Pain 2008;4:26. [PubMed: 18631385]

Fukuoka T, Kobayashi K, Yamanaka H, Obata K, Dai Y, Noguchi K. Comparative study of the distribution of the alpha-subunits of voltage-gated sodium channels in normal and axotomized rat dorsal root ganglion neurons. J. Comp. Neurol 2008;510:188-206. [PubMed: 18615542]

Gold MS, Weinreich D, Kim CS, Wang R, Treanor J, et al. Redistribution of Na(V)1.8 in uninjured axons enables neuropathic pain. J. Neurosci 2003;23:158-66. [PubMed: 12514212]

Griffin RS, Costigan M, Brenner GJ, Ma CH, Scholz J, et al. Complement induction in spinal cord microglia results in anaphylatoxin C5a-mediated pain hypersensitivity. J. Neurosci 2007;27:8699708. [PubMed: 17687047]

Griffin, RS.; Woolf, CJ. Pharmacology of analgesia (Chapter 16). In: Golan, DE.; Tashjian, AH.; Armstrong, E.; Armstrong, AW., editors. Principles of Pharmacology: The Pathophysiological Basis of Drug Therapy. Vol. 2nd ed.. Lippincott, Williams, and Wilkins; Baltimore, MD: 2007. p. 263-82.

Guo LH, Schluesener HJ. The innate immunity of the central nervous system in chronic pain: the role of Toll-like receptors. Cell Mol. Life Sci 2007;64:1128-36. [PubMed: 17440679]

Hains BC, Klein JP, Saab CY, Craner MJ, Black JA, Waxman SG. Upregulation of sodium channel Nav1.3 and functional involvement in neuronal hyperexcitability associated with central neuropathic pain after spinal cord injury. J. Neurosci 2003;23:8881-92. [PubMed: 14523090]

Hains BC, Waxman SG. Sodium channel expression and the molecular pathophysiology of pain after SCI. Prog. Brain Res 2007;161:195-203. [PubMed: 17618978]

Hansson P, Backonja M, Bouhassira D. Usefulness and limitations of quantitative sensory testing: clinical and research application in neuropathic pain states. Pain 2007;129:256-59. [PubMed: 17451879]

Haythornthwaite JA, Clark MR, Pappagallo M, Raja SN. Pain coping strategies play a role in the persistence of pain in post-herpetic neuralgia. Pain 2003;106:453-60. [PubMed: 14659529]

Hendrich J, Van Minh AT, Heblich F, Nieto-Rostro M, Watschinger K, et al. Pharmacological disruption of calcium channel trafficking by the alpha2delta ligand gabapentin. Proc. Natl. Acad. Sci. USA 2008;105:3628-33. [PubMed: 18299583]

Hoffmann T, Sauer SK, Horch RE, Reeh PW. Sensory transduction in peripheral nerve axons elicits ectopic action potentials. J. Neurosci 2008;28:6281-84. [PubMed: 18550771]

Hoyt SB, London C, Ok H, Gonzalez E, Duffy JL, et al. Benzazepinone Nav1.7 blockers: potential treatments for neuropathic pain. Bioorg. Med. Chem. Lett 2007;17:6172-77. [PubMed: 17889534]

Htut M, Misra P, Anand P, Birch R, Carlstedt T. Pain phenomena and sensory recovery following brachial plexus avulsion injury and surgical repairs. J. Hand. Surg 2006;31:596-605.

Huang J, Zhang X, McNaughton PA. Inflammatory pain: the cellular basis of heat hyperalgesia. Curr. Neuropharmacol 2006;4:197-206. [PubMed: 18615146]

Hucho T, Levine JD. Signaling pathways in sensitization: toward a nociceptor cell biology. Neuron 2007;55:365-76. [PubMed: 17678851]

Hudmon A, Choi JS, Tyrrell L, Black JA, Rush AM, et al. Phosphorylation of sodium channel Na(v)1.8 by p38 mitogen-activated protein kinase increases current density in dorsal root ganglion neurons. J. Neurosci 2008;28:3190-201. [PubMed: 18354022]

Indo Y. Molecular basis of congenital insensitivity to pain with anhidrosis (CIPA): mutations and polymorphisms in TRKA (NTRK1) gene encoding the receptor tyrosine kinase for nerve growth factor. Hum. Mutat 2001;18:462-71. [PubMed: 11748840]

Inoue $\mathrm{K}$. The function of microglia through purinergic receptors: neuropathic pain and cytokine release. Pharmacol. Ther 2006;109:210-26. [PubMed: 16169595]

Inoue $\mathrm{K}$, Koizumi S, Tsuda M. The role of nucleotides in the neuron-glia communication responsible for the brain functions. J. Neurochem 2007;102:1447-58. [PubMed: 17697046]

Iwata H, Takasusuki T, Yamaguchi S, Hori Y. NMDA receptor 2B subunit-mediated synaptic transmission in the superficial dorsal horn of peripheral nerve-injured neuropathic mice. Brain Res 2007;1135:92-101. [PubMed: 17198690]

Jarvis MF, Honore P, Shieh CC, Chapman M, Joshi S, et al. A-803467, a potent and selective Nav1.8 sodium channel blocker, attenuates neuropathic and inflammatory pain in the rat. Proc. Natl. Acad. Sci. USA 2007;104:8520-25. [PubMed: 17483457] 
Ji RR, Baba H, Brenner GJ, Woolf CJ. Nociceptive-specific activation of ERK in spinal neurons contributes to pain hypersensitivity. Nat. Neurosci 1999;2:1114-19. [PubMed: 10570489]

Ji RR, Suter MR. p38 MAPK, microglial signaling, and neuropathic pain. Mol. Pain 2007;3:33. [PubMed: 17974036]

Jimenez-Diaz L, Geranton SM, Passmore GM, Leith JL, Fisher AS, et al. Local translation in primary afferent fibers regulates nociception. PLoS ONE 2008;3:e1961. [PubMed: 18398477]

Jin X, Gereau RWt. Acute p38-mediated modulation of tetrodotoxin-resistant sodium channels in mouse sensory neurons by tumor necrosis factor-alpha. J. Neurosci 2006;26:246-55. [PubMed: 16399694]

Jorum E, Warncke T, Stubhaug A. Cold allodynia and hyperalgesia in neuropathic pain: the effect of Nmethyl-D-aspartate (NMDA) receptor antagonist ketamine-a double-blind, cross-over comparison with alfentanil and placebo. Pain 2003;101:229-35. [PubMed: 12583865]

Joshi SK, Mikusa JP, Hernandez G, Baker S, Shieh CC, et al. Involvement of the TTX-resistant sodium channel Nav 1.8 in inflammatory and neuropathic, but not post-operative, pain states. Pain 2006;123:75-82. [PubMed: 16545521]

Juhl GI, Jensen TS, Norholt SE, Svensson P. Central sensitization phenomena after third molar surgery: a quantitative sensory testing study. Eur. J. Pain 2008;12:116-27. [PubMed: 17553713]

Julien N, Goffaux P, Arsenault P, Marchand S. Widespread pain in fibromyalgia is related to a deficit of endogenous pain inhibition. Pain 2005;114:295-302. [PubMed: 15733656]

Kalliomaki ML, Meyerson J, Gunnarsson U, Gordh T, Sandblom G. Long-term pain after inguinal hernia repair in a population-based cohort; risk factors and interference with daily activities. Eur. J. Pain 2008;12:214-25. [PubMed: 17606392]

Kawasaki Y, Xu ZZ, Wang X, Park JY, Zhuang ZY, et al. Distinct roles of matrix metalloproteases in the early- and late-phase development of neuropathic pain. Nat. Med 2008;14:331-36. [PubMed: 18264108]

Kehlet H, Jensen TS, Woolf CJ. Persistent postsurgical pain: risk factors and prevention. Lancet 2006;367:1618-25. [PubMed: 16698416]

Keller AF, Beggs S, Salter MW, De Koninck Y. Transformation of the output of spinal lamina I neurons after nerve injury and microglia stimulation underlying neuropathic pain. Mol. Pain 2007;3:27. [PubMed: 17900333]

Ketz AK. The experience of phantom limb pain in patients with combat-related traumatic amputations. Arch. Phys. Med. Rehabil 2008;89:1127-32. [PubMed: 18503810]

Khan GM, Chen SR, Pan HL. Role of primary afferent nerves in allodynia caused by diabetic neuropathy in rats. Neuroscience 2002;114:291-99. [PubMed: 12204199]

Kim SH, Chung JM. An experimental model for peripheral neuropathy produced by segmental spinal nerve ligation in the rat. Pain 1992;50:355-63. [PubMed: 1333581]

Knabl J, Witschi R, Hosl K, Reinold H, Zeilhofer UB, et al. Reversal of pathological pain through specific spinal GABAA receptor subtypes. Nature 2008;451:330-34. [PubMed: 18202657]

Kohama I, Ishikawa K, Kocsis JD. Synaptic reorganization in the substantia gelatinosa after peripheral nerve neuroma formation: aberrant innervation of lamina II neurons by Abeta afferents. J. Neurosci 2000;20:1538-49. [PubMed: 10662843]

Kohno T, Ji RR, Ito N, Allchorne AJ, Befort K, et al. Peripheral axonal injury results in reduced mu opioid receptor pre- and post-synaptic action in the spinal cord. Pain 2005;117:77-87. [PubMed: 16098668]

Koltzenburg M, Torebjork HE, Wahren LK. Nociceptor modulated central sensitization causes mechanical hyperalgesia in acute chemogenic and chronic neuropathic pain. Brain 1994;117(Pt 3): 579-91. [PubMed: 8032867]

LaBuda CJ, Little PJ. Pharmacological evaluation of the selective spinal nerve ligation model of neuropathic pain in the rat. J. Neurosci. Methods 2005;144:175-81. [PubMed: 15910975]

Lang PM, Fleckenstein J, Passmore GM, Brown DA, Grafe P. Retigabine reduces the excitability of unmyelinated peripheral human axons. Neuropharmacology 2008;54:1271-78. [PubMed: 18474382]

Li CY, Song YH, Higuera ES, Luo ZD. Spinal dorsal horn calcium channel alpha2delta-1 subunit upregulation contributes to peripheral nerve injury-induced tactile allodynia. J. Neurosci 2004;24:8494-99. [PubMed: 15456823] 
Lotsch J, Geisslinger G. Current evidence for a modulation of nociception by human genetic polymorphisms. Pain 2007;132:18-22. [PubMed: 17706868]

Lu Y, Perl ER. Modular organization of excitatory circuits between neurons of the spinal superficial dorsal horn (laminae I and II). J. Neurosci 2005;25:3900-7. [PubMed: 15829642]

Luo L, Chang L, Brown SM, Ao H, Lee DH, et al. Role of peripheral hyperpolarization-activated cyclic nucleotide-modulated channel pacemaker channels in acute and chronic pain models in the rat. Neuroscience 2007;144:1477-85. [PubMed: 17196750]

Maguire MF, Ravenscroft A, Beggs D, Duffy JP. A questionnaire study investigating the prevalence of the neuropathic component of chronic pain after thoracic surgery. Eur. J. Cardiothorac. Surg 2006;29:800-5. [PubMed: 16581259]

Malmberg AB, Chen C, Tonegawa S, Basbaum AI. Preserved acute pain and reduced neuropathic pain in mice lacking PKCgamma. Science 1997;278:279-83. [PubMed: 9323205]

Matsumoto M, Xie W, Ma L, Ueda H. Pharmacological switch in Abeta-fiber stimulation-induced spinal transmission in mice with partial sciatic nerve injury. Mol. Pain 2008;4:25. [PubMed: 18620588]

Matsuzawa-Yanagida K, Narita M, Nakajima M, Kuzumaki N, Niikura K, et al. Usefulness of antidepressants for improving the neuropathic pain-like state and pain-induced anxiety through actions at different brain sites. Neuropsychopharmacology 2008;33:1952-65. [PubMed: 17957217]

May A. Neuroimaging: visualising the brain in pain. Neurol. Sci 2007;28(Suppl 2):S101-7. [PubMed: 17508154]

May A. Chronic pain may change the structure of the brain. Pain 2008;137:7-15. [PubMed: 18410991]

McGivern JG. Targeting N-type and T-type calcium channels for the treatment of pain. Drug Discov. Today 2006;11:245-53. [PubMed: 16580601]

Michaud K, Bombardier C, Emery P. Quality of life in patients with rheumatoid arthritis: Does abatacept make a difference? Clin. Exp. Rheumatol 2007;25:S35-45. [PubMed: 17977487]

Mika J. Modulation of microglia can attenuate neuropathic pain symptoms and enhance morphine effectiveness. Pharmacol. Rep 2008;60:297-307. [PubMed: 18622054]

Milligan ED, Sloane EM, Watkins LR. Glia in pathological pain: a role for fractalkine. J. Neuroimmunol 2008;198:113-20. [PubMed: 18547654]

Miraucourt LS, Dallel R, Voisin DL. Glycine inhibitory dysfunction turns touch into pain through PKCgamma interneurons. PLoS ONE 2007;2:e1116. [PubMed: 17987109]

Miyabe T, Miletic G, Miletic V. Loose ligation of the sciatic nerve in rats elicits transient up-regulation of Homer1a gene expression in the spinal dorsal horn. Neurosci. Lett 2006;398:296-99. [PubMed: 16448751]

Mogil JS, Wilson SG, Bon K, Lee SE, Chung K, et al. Heritability of nociception I: responses of 11 inbred mouse strains on 12 measures of nociception. Pain 1999a;80:67-82. [PubMed: 10204719]

Mogil JS, Wilson SG, Bon K, Lee SE, Chung K, et al. Heritability of nociception II. 'Types' of nociception revealed by genetic correlation analysis. Pain 1999b;80:83-93. [PubMed: 10204720]

Mogil JS, Wilson SG, Chesler EJ, Rankin AL, Nemmani KV, et al. The melanocortin-1 receptor gene mediates female-specific mechanisms of analgesia in mice and humans. Proc. Natl. Acad. Sci. USA 2003;100:4867-72. [PubMed: 12663858]

Moore KA, Kohno T, Karchewski LA, Scholz J, Baba H, Woolf CJ. Partial peripheral nerve injury promotes a selective loss of GABAergic inhibition in the superficial dorsal horn of the spinal cord. J. Neurosci 2002;22:6724-31. [PubMed: 12151551]

Moss A, Beggs S, Vega-Avelaira D, Costigan M, Hathway GJ, et al. Spinal microglia and neuropathic pain in young rats. Pain 2007;128:215-24. [PubMed: 17110040]

Nackley AG, Shabalina SA, Tchivileva IE, Satterfield K, Korchynskyi O, et al. Human catechol-Omethyltransferase haplotypes modulate protein expression by altering mRNA secondary structure. Science 2006;314:1930-33. [PubMed: 17185601]

Nassar MA, Baker MD, Levato A, Ingram R, Mallucci G, et al. Nerve injury induces robust allodynia and ectopic discharges in Nav1.3 null mutant mice. Mol. Pain 2006;2:33. [PubMed: 17052333]

Nassar MA, Levato A, Stirling LC, Wood JN. Neuropathic pain develops normally in mice lacking both Nav1.7 and Nav1.8. Mol. Pain 2005;1:24. [PubMed: 16111501] 
Neumann S, Braz JM, Skinner K, Llewellyn-Smith IJ, Basbaum AI. Innocuous, not noxious, input activates PKCgamma interneurons of the spinal dorsal horn via myelinated afferent fibers. J. Neurosci 2008;28:7936-44. [PubMed: 18685019]

Nielsen CS, Stubhaug A, Price DD, Vassend O, Czajkowski N, Harris JR. Individual differences in pain sensitivity: genetic and environmental contributions. Pain 2008;136:21-29. [PubMed: 17692462]

Nieto FR, Entrena JM, Cendan CM, Pozo ED, Vela JM, Baeyens JM. Tetrodotoxin inhibits the development and expression of neuropathic pain induced by paclitaxel in mice. Pain 2008;137:52031. [PubMed: 18037242]

Norbury TA, MacGregor AJ, Urwin J, Spector TD, McMahon SB. Heritability of responses to painful stimuli in women: a classical twin study. Brain 2007;130:3041-49. [PubMed: 17932101]

Obata K, Katsura H, Miyoshi K, Kondo T, Yamanaka H, et al. Toll-like receptor 3 contributes to spinal glial activation and tactile allodynia after nerve injury. J. Neurochem. 2009In press

Obata K, Yamanaka H, Fukuoka T, Yi D, Tokunaga A, et al. Contribution of injured and uninjured dorsal root ganglion neurons to pain behavior and the changes in gene expression following chronic constriction injury of the sciatic nerve in rats. Pain 2003;101:65-77. [PubMed: 12507701]

Okamoto M, Baba H, Goldstein PA, Higashi H, Shimoji K, Yoshimura M. Functional reorganization of sensory pathways in the rat spinal dorsal horn following peripheral nerve injury. J. Physiol 2001;532:241-50. [PubMed: 11283238]

Pedersen LH, Scheel-Kruger J, Blackburn-Munro G. Amygdala GABA-A receptor involvement in mediating sensory-discriminative and affective-motivational pain responses in a rat model of peripheral nerve injury. Pain 2007;127:17-26. [PubMed: 16965855]

Peltier AC, Russell JW. Recent advances in drug-induced neuropathies. Curr. Opin. Neurol 2002;15:63338. [PubMed: 12352008]

Perl ER. Ideas about pain, a historical view. Nat. Rev. Neurosci 2007;8:71-80. [PubMed: 17180164]

Pertin M, Ji RR, Berta T, Powell AJ, Karchewski L, et al. Upregulation of the voltage-gated sodium channel beta2 subunit in neuropathic pain models: characterization of expression in injured and non-injured primary sensory neurons. J. Neurosci 2005;25:10970-80. [PubMed: 16306410]

Pinto V, Derkach VA, Safronov BV. Role of TTX-sensitive and TTX-resistant sodium channels in Adelta- and C-fiber conduction and synaptic transmission. J. Neurophysiol 2008;99:617-28. [PubMed: 18057109]

Poleshuck EL, Katz J, Andrus CH, Hogan LA, Jung BF, et al. Risk factors for chronic pain following breast cancer surgery: a prospective study. J. Pain 2006;7:626-34. [PubMed: 16942948]

Polgar E, Hughes DI, Arham AZ, Todd AJ. Loss of neurons from laminas I-III of the spinal dorsal horn is not required for development of tactile allodynia in the spared nerve injury model of neuropathic pain. J. Neurosci 2005;25:6658-66. [PubMed: 16014727]

Rahman W, D’Mello R, Dickenson AH. Peripheral nerve injury-induced changes in spinal alpha(2)adrenoceptor-mediated modulation of mechanically evoked dorsal horn neuronal responses. J. Pain 2008;9:350-59. [PubMed: 18226963]

Romero-Sandoval EA, Horvath RJ, DeLeo JA. Neuroimmune interactions and pain: focus on glialmodulating targets. Curr. Opin. Investig. Drugs 2008;9:726-34.

Rowbotham MC, Fields HL. The relationship of pain, allodynia and thermal sensation in post-herpetic neuralgia. Brain 1996;119(Pt 2):347-54. [PubMed: 8800931]

Roza C, Laird JM, Souslova V, Wood JN, Cervero F. The tetrodotoxin-resistant Na+ channel Nav1.8 is essential for the expression of spontaneous activity in damaged sensory axons of mice. J. Physiol 2003;550:921-26. [PubMed: 12824446]

Roza C, Lopez-Garcia JA. Retigabine, the specific KCNQ channel opener, blocks ectopic discharges in axotomized sensory fibres. Pain 2008;138(3):537-45. [PubMed: 18331780]

Saab CY, Waxman SG, Hains BC. Alarm or curse? The pain of neuroinflammation. Brain Res. Rev 2008;58:226-35. [PubMed: 18486228]

Saegusa H, Kurihara T, Zong S, Kazuno A, Matsuda Y, et al. Suppression of inflammatory and neuropathic pain symptoms in mice lacking the N-type $\mathrm{Ca}^{2+}$ channel. EMBO J 2001;20:2349-56. [PubMed: 11350923] 
Sarantopoulos CD, McCallum JB, Rigaud M, Fuchs A, Kwok WM, Hogan QH. Opposing effects of spinal nerve ligation on calcium-activated potassium currents in axotomized and adjacent mammalian primary afferent neurons. Brain Res 2007;1132:84-99. [PubMed: 17184741]

Schmalhofer W, Calhoun J, Burrows R, Bailey T, Kohler MG, et al. ProTx-II, a selective inhibitor of NaV1.7 sodium channels, blocks action potential propagation in nociceptors. Mol. Pharmacol 2008;74(5):1476-84. [PubMed: 18728100]

Scholz J, Abele A, Marian C, Haussler A, Herbert TA, et al. Low-dose methotrexate reduces peripheral nerve injury-evoked spinal microglial activation and neuropathic pain behavior in rats. Pain 2008;138:130-42. [PubMed: 18215468]

Scholz J, Broom DC, Youn DH, Mills CD, Kohno T, et al. Blocking caspase activity prevents transsynaptic neuronal apoptosis and the loss of inhibition in lamina II of the dorsal horn after peripheral nerve injury. J. Neurosci 2005;25:7317-23. [PubMed: 16093381]

Scholz J, Woolf CJ. The neuropathic pain triad: neurons, immune cells and glia. Nat. Neurosci 2007;10:1361-68. [PubMed: 17965656]

Seijffers R, Mills CD, Woolf CJ. ATF3 increases the intrinsic growth state of DRG neurons to enhance peripheral nerve regeneration. J. Neurosci 2007;27:7911-20. [PubMed: 17652582]

Seltzer Z, Dubner R, Shir Y. A novel behavioral model of neuropathic pain disorders produced in rats by partial sciatic nerve injury. Pain 1990;43:205-18. [PubMed: 1982347]

Sheets PL, Heers C, Stoehr T, Cummins TR. Differential block of sensory neuronal voltage-gated sodium channels by lacosamide [(2R)-2-(acetylamino)-N-benzyl-3-methoxypropanamide], lidocaine, and carbamazepine. J. Pharmacol. Exp. Ther 2008;326:89-99. [PubMed: 18378801]

Soares S, Barnat M, Salim C, von Boxberg Y, Ravaille-Veron M, Nothias F. Extensive structural remodeling of the injured spinal cord revealed by phosphorylated MAP1B in sprouting axons and degenerating neurons. Eur. J. Neurosci 2007;26:1446-61. [PubMed: 17880387]

Soares S, von Boxberg Y, Lombard MC, Ravaille-Veron M, Fischer I, et al. Phosphorylated MAP1B is induced in central sprouting of primary afferents in response to peripheral injury but not in response to rhizotomy. Eur. J. Neurosci 2002;16:593-606. [PubMed: 12270035]

Staud R, Craggs JG, Perlstein WM, Robinson ME, Price DD. Brain activity associated with slow temporal summation of C-fiber evoked pain in fibromyalgia patients and healthy controls. Eur. J. Pain 2008;12(8):1078-89. [PubMed: 18367419]

Staud R, Robinson ME, Price DD. Temporal summation of second pain and its maintenance are useful for characterizing widespread central sensitization of fibromyalgia patients. J. Pain 2007;8:893901. [PubMed: 17681887]

Staud R, Rodriguez ME. Mechanisms of disease: pain in fibromyalgia syndrome. Nat. Clin. Pract. Rheumatol 2006;2:90-98. [PubMed: 16932662]

Sullivan KA, Lentz SI, Roberts JL Jr, Feldman EL. Criteria for creating and assessing mouse models of diabetic neuropathy. Curr. Drug Targets 2008;9:3-13. [PubMed: 18220709]

Suter MR, Wen YR, Decosterd I, Ji RR. Do glial cells control pain? Neuron. Glia Biol 2007;3:255-68. [PubMed: 18504511]

Takasusuki T, Fujiwara T, Yamaguchi S, Fukushima T, Akagawa K, Hori Y. Enhancement of synaptic transmission and nociceptive behaviour in HPC-1/syntaxin 1A knockout mice following peripheral nerve injury. Eur. J. Neurosci 2007;26:2179-87. [PubMed: 17953616]

Tandrup T, Woolf CJ, Coggeshall RE. Delayed loss of small dorsal root ganglion cells after transection of the rat sciatic nerve. J. Comp. Neurol 2000;422:172-80. [PubMed: 10842225]

Tao YX, Rumbaugh G, Wang GD, Petralia RS, Zhao C, et al. Impaired NMDA receptor-mediated postsynaptic function and blunted NMDA receptor-dependent persistent pain in mice lacking postsynaptic density-93 protein. J. Neurosci 2003;23:6703-12. [PubMed: 12890763]

Tegeder I, Adolph J, Schmidt H, Woolf CJ, Geisslinger G, Lotsch J. Reduced hyperalgesia in homozygous carriers of a GTP cyclohydrolase 1 haplotype. Eur. J. Pain 2008;12(8):1069-77. [PubMed: 18374612]

Tegeder I, Costigan M, Griffin RS, Abele A, Belfer I, et al. GTP cyclohydrolase and tetrahydrobiopterin regulate pain sensitivity and persistence. Nat. Med 2006;12:1269-77. [PubMed: 17057711] 
Thompson SW, Woolf CJ, Sivilotti LG. Small-caliber afferent inputs produce a heterosynaptic facilitation of the synaptic responses evoked by primary afferent A-fibers in the neonatal rat spinal cord in vitro. J. Neurophysiol 1993;69:2116-28. [PubMed: 8350135]

Torrance N, Smith BH, Bennett MI, Lee AJ. The epidemiology of chronic pain of predominantly neuropathic origin. Results from a general population survey. J. Pain 2006;7:281-89. [PubMed: 16618472]

Torres L, Dunlop DD, Peterfy C, Guermazi A, Prasad P, et al. The relationship between specific tissue lesions and pain severity in persons with knee osteoarthritis. Osteoarthritis Cartilage 2006;14:103340. [PubMed: 16713310]

Torsney C, MacDermott AB. Disinhibition opens the gate to pathological pain signaling in superficial neurokinin 1 receptor-expressing neurons in rat spinal cord. J. Neurosci 2006;26:1833-43. [PubMed: 16467532]

Tracey I. Imaging pain. Br. J. Anaesth 2008;101:32-39. [PubMed: 18556697]

Tracey I, Mantyh PW. The cerebral signature for pain perception and its modulation. Neuron 2007;55:377-91. [PubMed: 17678852]

Trang T, Beggs S, Salter MW. Purinoceptors in microglia and neuropathic pain. Pflugers Arch 2006;452:645-52. [PubMed: 16767466]

Treede RD, Jensen TS, Campbell JN, Cruccu G, Dostrovsky JO, et al. Neuropathic pain: redefinition and a grading system for clinical and research purposes. Neurology 2008;70:1630-35. [PubMed: 18003941]

Ultenius C, Linderoth B, Meyerson BA, Wallin J. Spinal NMDA receptor phosphorylation correlates with the presence of neuropathic signs following peripheral nerve injury in the rat. Neurosci. Lett 2006;399:85-90. [PubMed: 16469445]

Vera-Portocarrero LP, Zhang ET, Ossipov MH, Xie JY, King T, et al. Descending facilitation from the rostral ventromedial medulla maintains nerve injury-induced central sensitization. Neuroscience 2006;140:1311-20. [PubMed: 16650614]

Vierck CJ, Hansson PT, Yezierski RP. Clinical and pre-clinical pain assessment: Are we measuring the same thing? Pain 2008;135:7-10. [PubMed: 18215466]

Wall PD, Devor M, Inbal R, Scadding JW, Schonfeld D, et al. Autotomy following peripheral nerve lesions: experimental anesthesia dolorosa. Pain 1979;7:103-11. [PubMed: 574931]

Wallace VC, Blackbeard J, Pheby T, Segerdahl AR, Davies M, et al. Pharmacological, behavioural and mechanistic analysis of HIV-1 gp120 induced painful neuropathy. Pain 2007;133:47-63. [PubMed: 17433546]

Wallace VC, Cottrell DF, Brophy PJ, Fleetwood-Walker SM. Focal lysolecithin-induced demyelination of peripheral afferents results in neuropathic pain behavior that is attenuated by cannabinoids. J. Neurosci 2003;23:3221-33. [PubMed: 12716929]

Watanabe K, Konno S, Sekiguchi M, Sasaki N, Honda T, Kikuchi S. Increase of 200-kDa neurofilamentimmunoreactive afferents in the substantia gelatinosa in allodynic rats induced by compression of the dorsal root ganglion. Spine 2007;32:1265-71. [PubMed: 17515813]

Watkins LR, Hutchinson MR, Ledeboer A, Wieseler-Frank J, Milligan ED, Maier SF. Norman Cousins lecture. Glia as the "bad guys": implications for improving clinical pain control and the clinical utility of opioids. Brain Behav. Immun 2007;21:131-46. [PubMed: 17175134]

Watkins LR, Hutchinson MR, Milligan ED, Maier SF. "Listening” and "talking” to neurons: implications of immune activation for pain control and increasing the efficacy of opioids. Brain Res. Rev 2007;56:148-69. [PubMed: 17706291]

Wellcome-Consort. Genome-wide association study of 14,000 cases of seven common diseases and 3,000 shared controls. Nature 2007;447:661-78. [PubMed: 17554300]

White FA, Jung H, Miller RJ. Chemokines and the pathophysiology of neuropathic pain. Proc. Natl. Acad. Sci. USA 2007;104:20151-58. [PubMed: 18083844]

Witting N, Kupers RC, Svensson P, Jensen TS. A PET activation study of brush-evoked allodynia in patients with nerve injury pain. Pain 2006;120:145-54. [PubMed: 16368192]

Woodbury CJ, Kullmann FA, McIlwrath SL, Koerber HR. Identity of myelinated cutaneous sensory neurons projecting to nocireceptive laminae following nerve injury in adult mice. J. Comp. Neurol 2008;508:500-9. [PubMed: 18335545] 
Woolf CJ, Ma Q. Nociceptors-noxious stimulus detectors. Neuron 2007;55:353-64. [PubMed: 17678850]

Woolf CJ, Mannion RJ. Neuropathic pain: aetiology, symptoms, mechanisms, and management. Lancet 1999;353:1959-64. [PubMed: 10371588]

Woolf CJ, Salter MW. Neuronal plasticity: increasing the gain in pain. Science 2000;288:1765-69. [PubMed: 10846153]

Woolf CJ, Shortland P, Coggeshall RE. Peripheral nerve injury triggers central sprouting of myelinated afferents. Nature 1992;355:75-78. [PubMed: 1370574]

Wu G, Ringkamp M, Murinson BB, Pogatzki EM, Hartke TV, et al. Degeneration of myelinated efferent fibers induces spontaneous activity in uninjured C-fiber afferents. J. Neurosci 2002;22:7746-53. [PubMed: 12196598]

Yamamoto W, Sugiura A, Nakazato-Imasato E, Kita Y. Characterization of primary sensory neurons mediating static and dynamic allodynia in rat chronic constriction injury model. J. Pharm. Pharmacol 2008;60:717-22. [PubMed: 18498707]

Yudin D, Hanz S, Yoo S, Iavnilovitch E, Willis D, et al. Localized regulation of axonal RanGTPase controls retrograde injury signaling in peripheral nerve. Neuron 2008;59:241-52. [PubMed: 18667152]

Zhu W, Oxford GS. Phosphoinositide-3-kinase and mitogen activated protein kinase signaling pathways mediate acute NGF sensitization of TRPV1. Mol. Cell Neurosci 2007;34:689-700. [PubMed: $17324588]$ 
a

Nociceptive pain

No nervous system lesion or inflammation

Stimulus-dependent pain

Evoked by high-intensity (noxious) stimuli

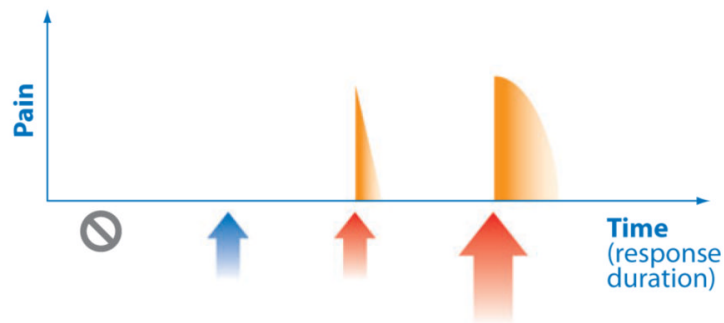

Adaptive

Protects by signaling potential tissue damage

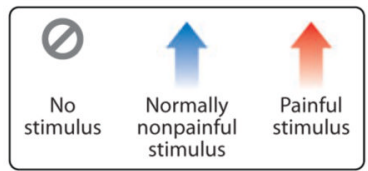

b

\section{Inflammatory pain}

Active inflammation

Spontaneous and stimulus-dependent pain

Sensory amplification

Evoked by low- and high-intensity stimuli

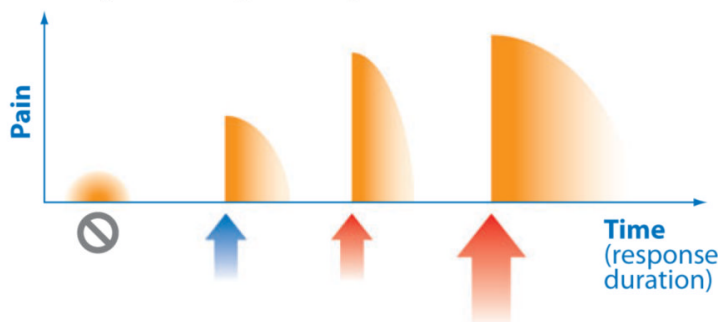

Adaptive and reversible

Protects by producing pain hypersensitivity during healing

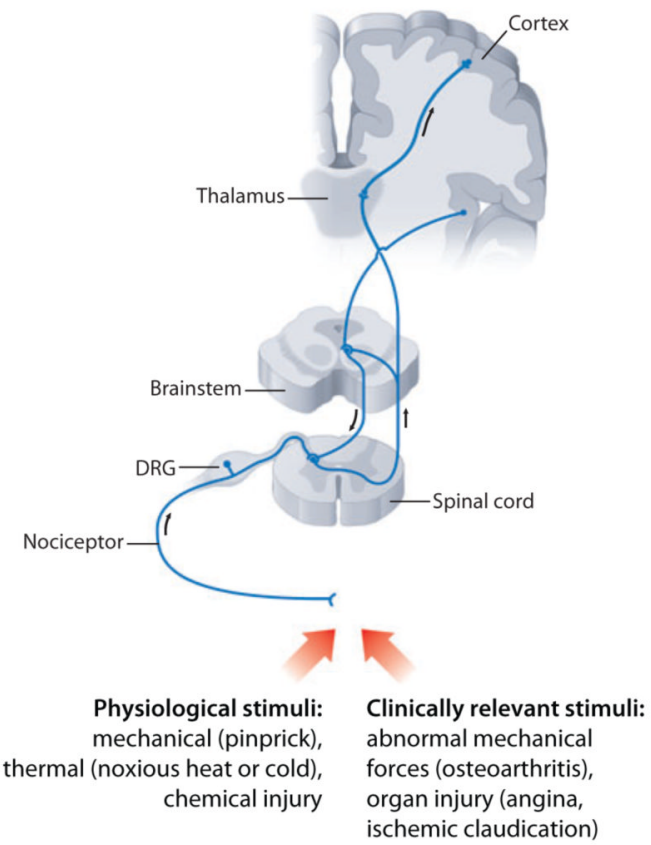

ischemic claudication)

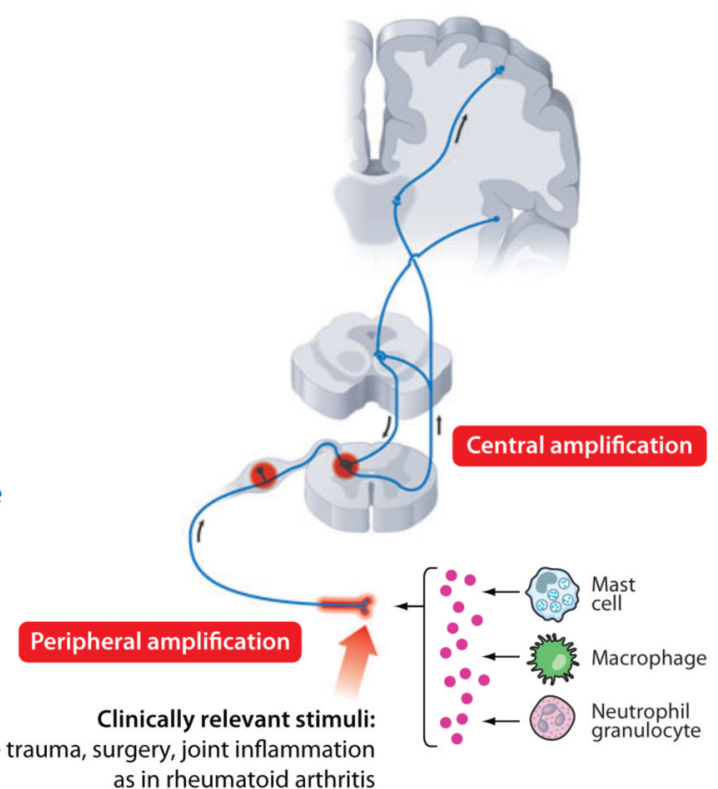

Annu Rev Neurosci. Author manuscript; available in PMC 2010 January 1. 
C

\section{Dysfunctional pain}

No known structural nervous system lesion or active peripheral inflammation

Spontaneous and stimulus-dependent pain

Sensory amplification

Evoked by low- and high-intensity

Present with lack of stimulus
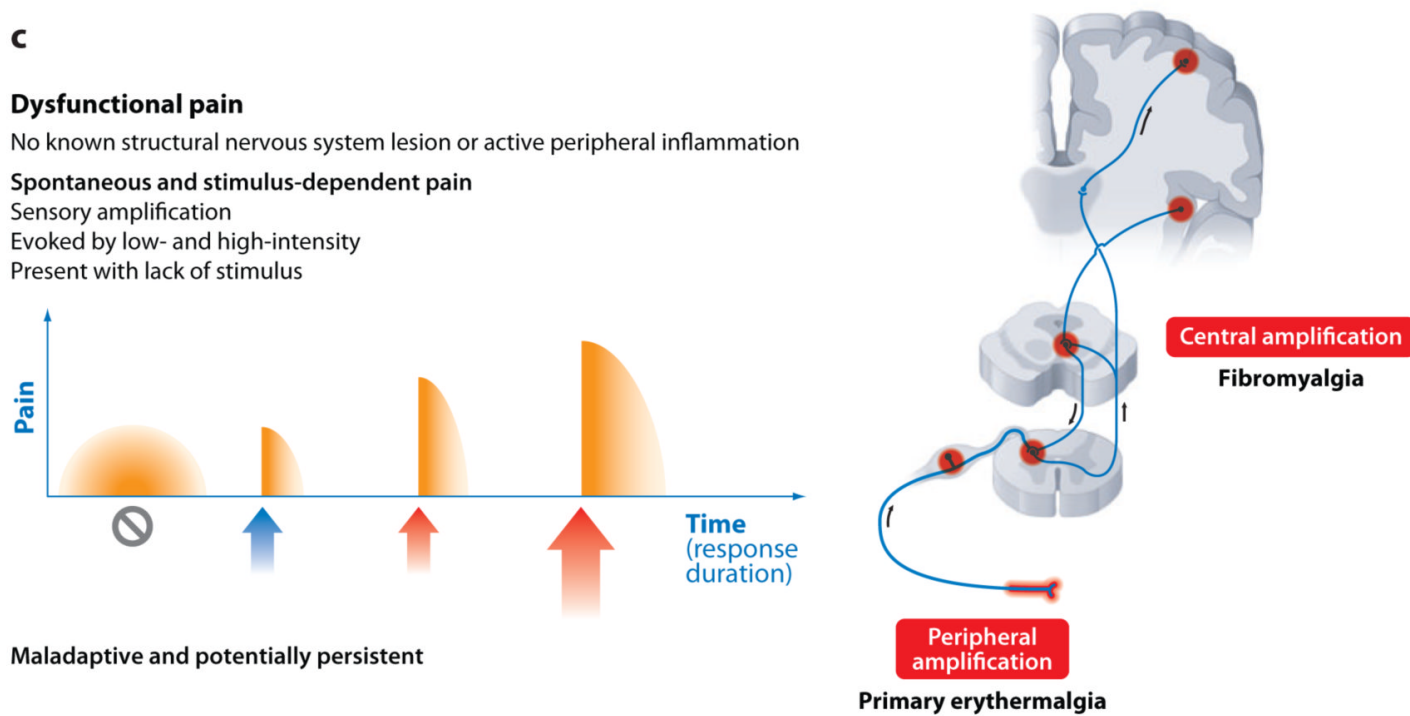

Maladaptive and potentially persistent

Primary erythermalgia

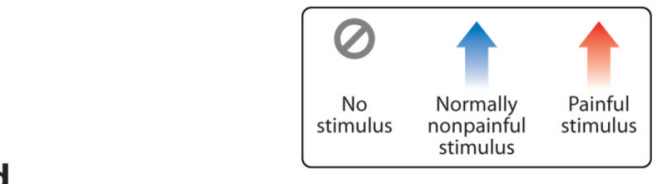

d

\section{Neuropathic pain}

Nervous system lesion or disease Marked neuroimmune response

Spontaneous and stimulus-dependent pain

Sensory amplification

Evoked by low- and high-intensity stimuli

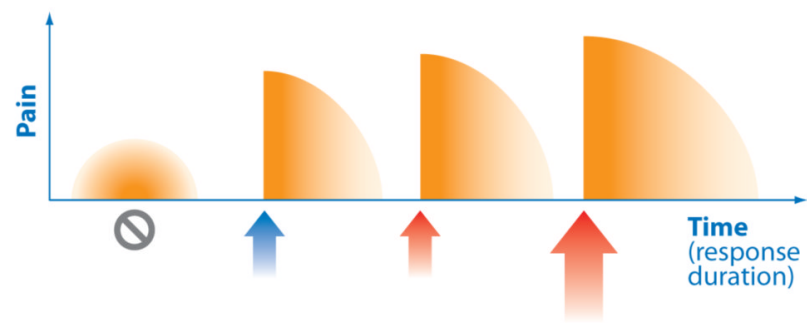

Maladaptive and commonly persistent

Abnormal amplification maintained independent of the lesion or disease
CNS lesion or disease: Stroke, spinal cord injury, multiple sclerosis

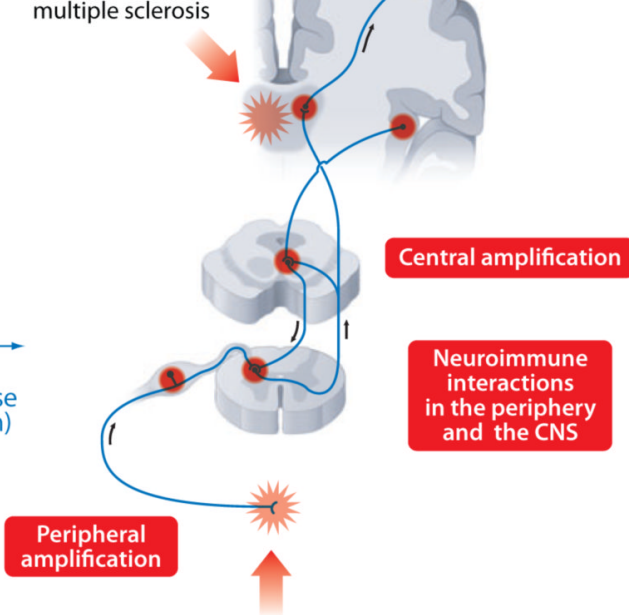

PNS lesion or disease: nerve trauma, toxic and metabolic neuropathies,

Herpes zoster, AIDS

Figure 1.

Pain syndromes. A summary of key features that distinguish and characterize the four major pain syndromes; nociceptive pain $(a)$, inflammatory pain $(b)$, dysfunctional pain $(c)$, and neuropathic pain $(d)$. (Image adapted from Griffin \& Woolf 2007) 


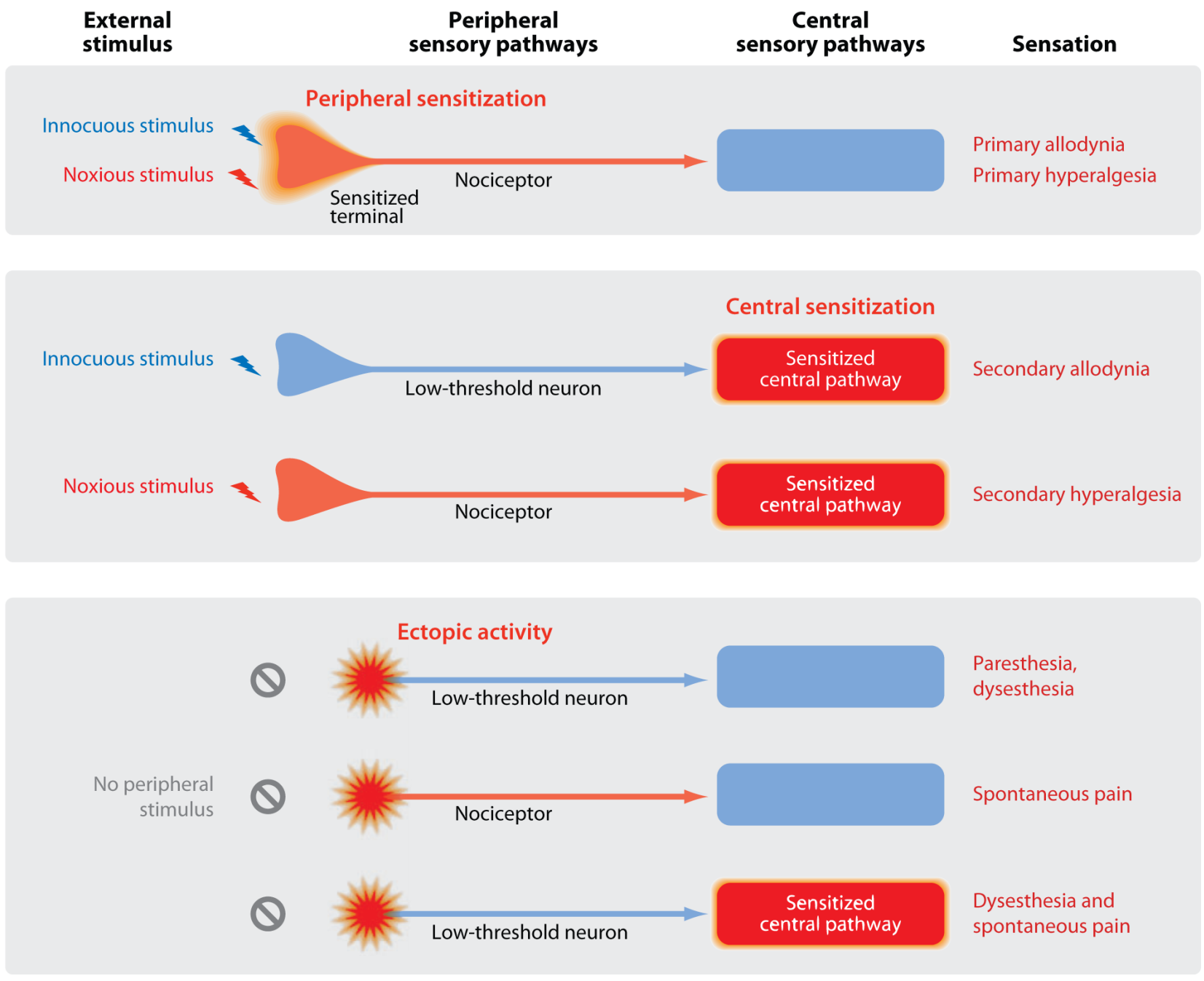

Figure 2.

Stimulus-response relations and pain mechanisms. A representation of the relationship between external noxious and innocuous stimuli and the sensory responses they evoke, depending on which afferent fiber is activated (nociceptor or low-threshold neuron) and whether the sensitivity of either the peripheral nervous system (PNS) or the central nervous system (CNS) is disturbed to amplify the response to stimuli (sensitization) and generate ectopic impulses. 

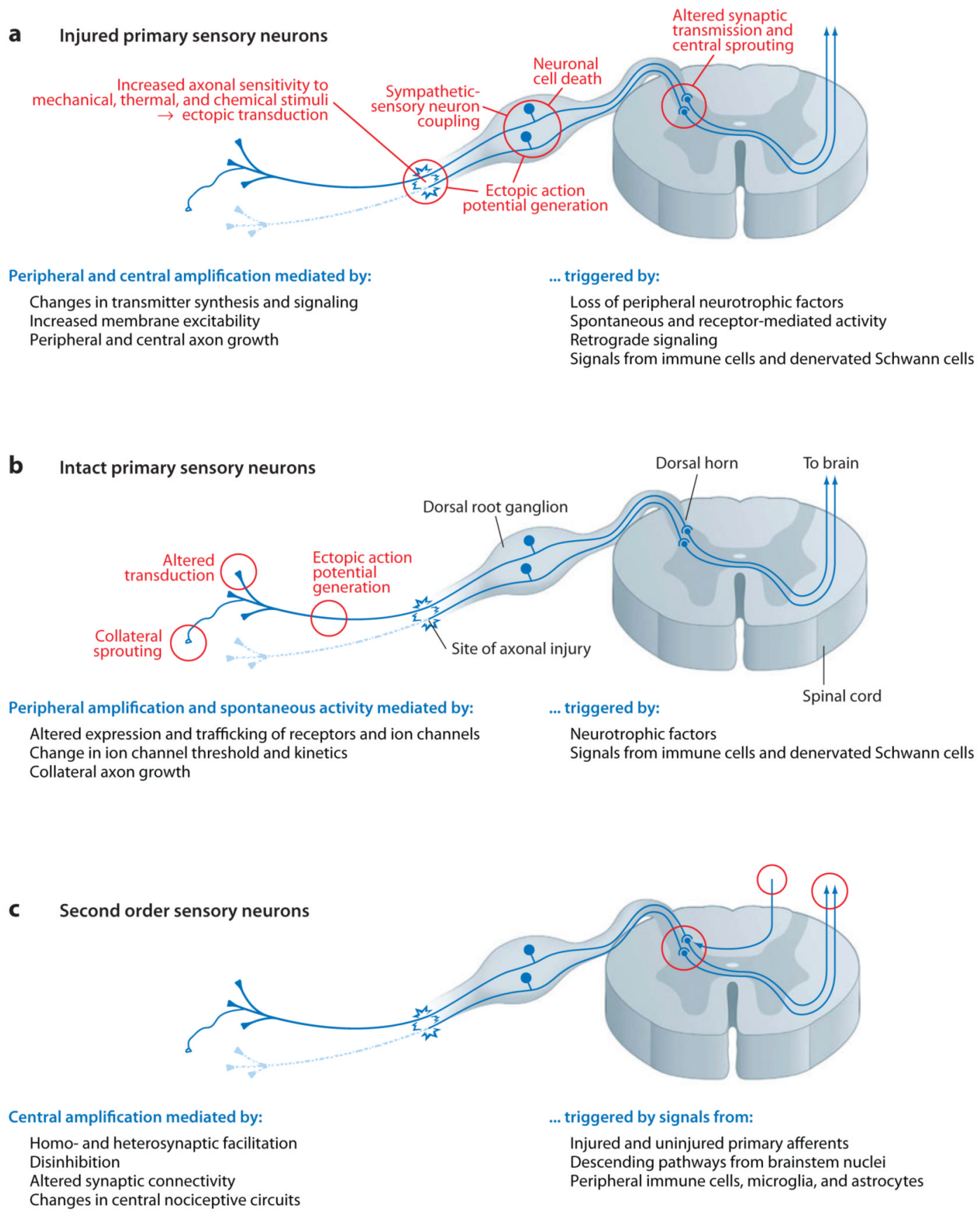

Figure 3.

A summary of the major mechanisms underlying peripheral neuropathic pain, their location, and the triggers responsible for their activation. (Image adapted from Griffin \& Woolf 2007) 
a
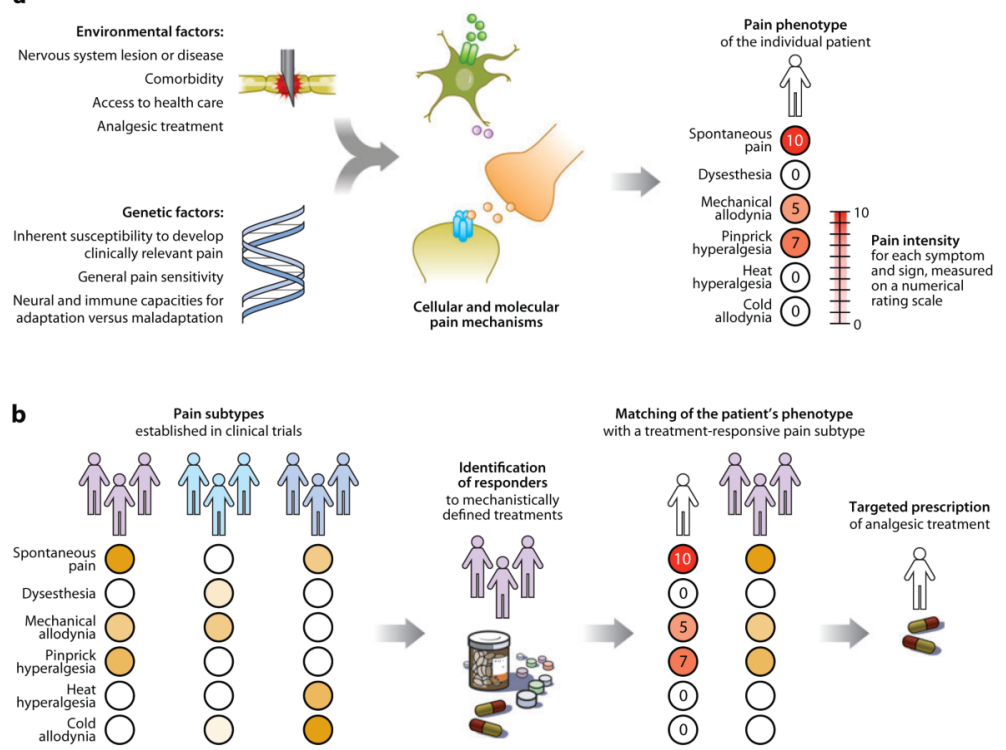

Figure 4.

Phenotypic classification of pain. (a) Environmental and genetic factors determine the recruitment of adaptive and maladaptive neurobiological mechanisms. Patients will, depending on the mechanisms active, exhibit distinct constellations of symptoms and signs that constitute their pain phenotype. (b) When symptoms and signs are evaluated with standardized assessment tools, the phenotype of an individual patient can be compared with pain subtypes established in clinical trials. Correlation of treatment response with a matching pain subtype will then allow targeted analgesic therapy. 


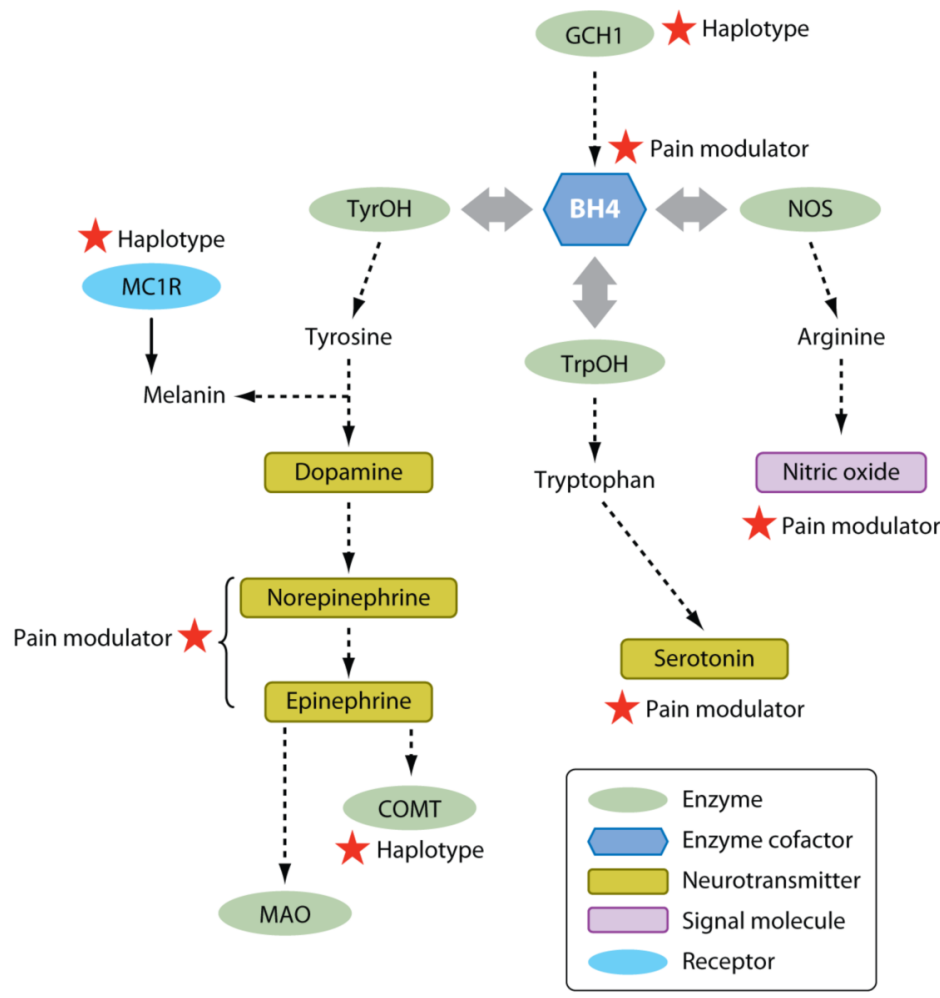

Figure 5.

A summary of the major mechanisms connecting tetrahydrobiopterin (BH4) functions as a cofactor and its role in chronic pain. 


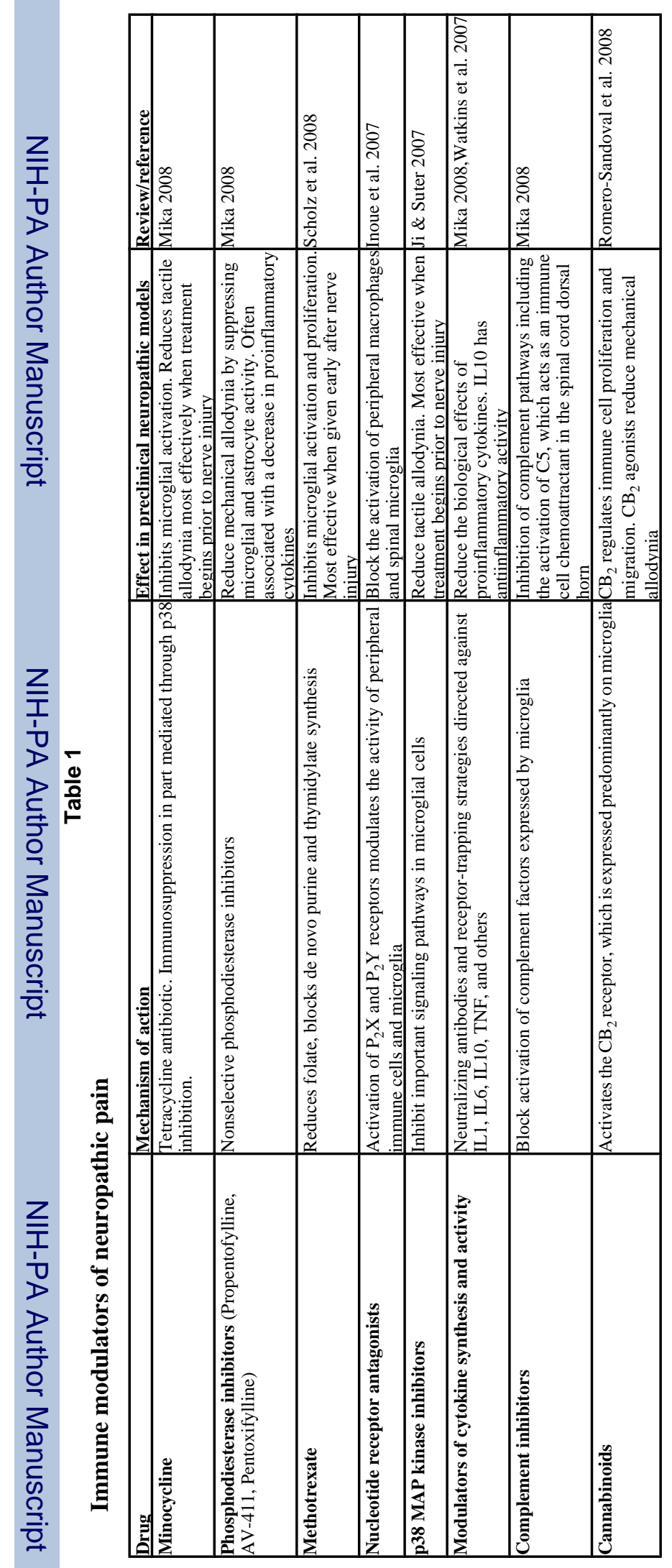

Annu Rev Neurosci. Author manuscript; available in PMC 2010 January 1. 


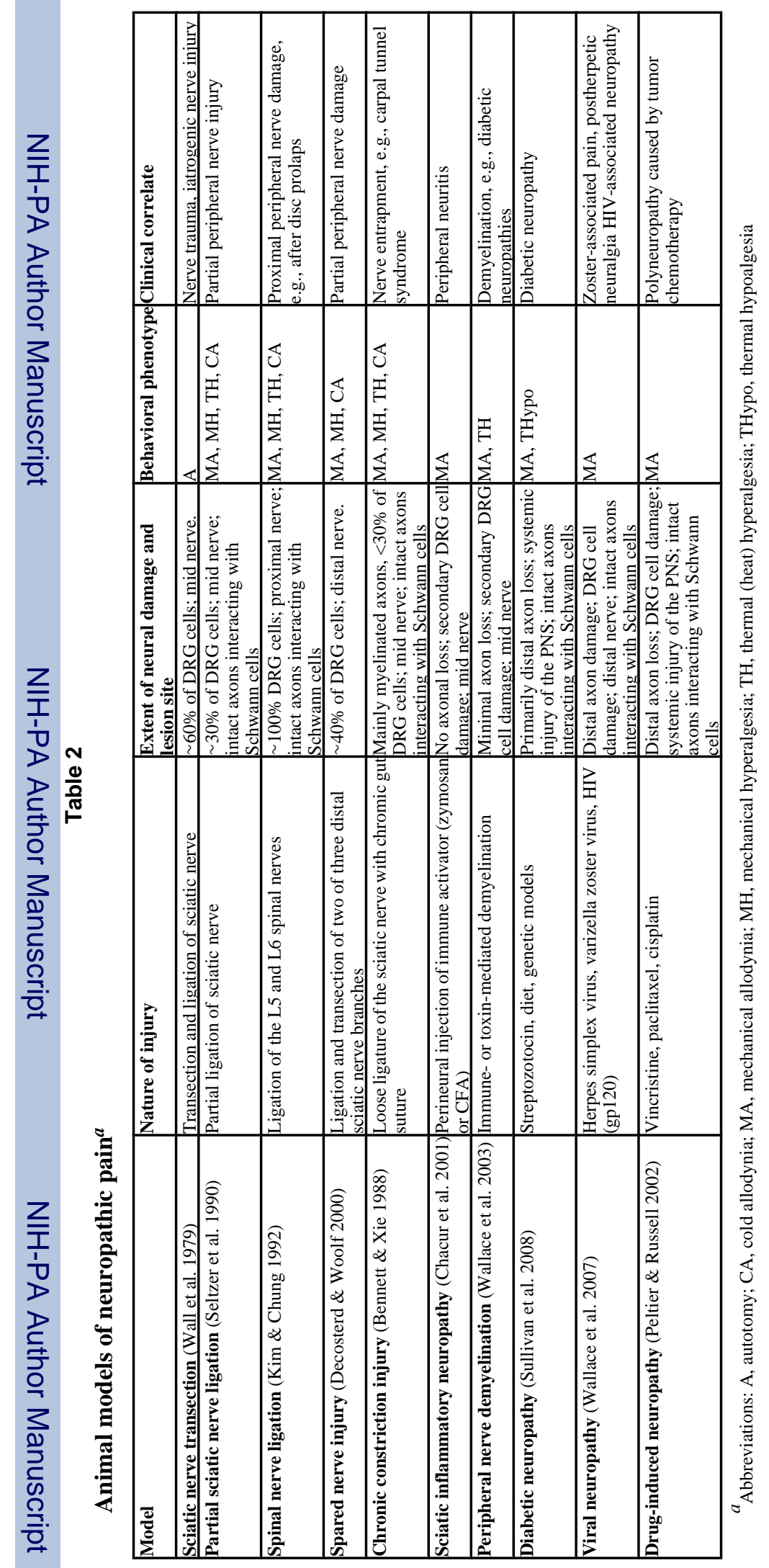




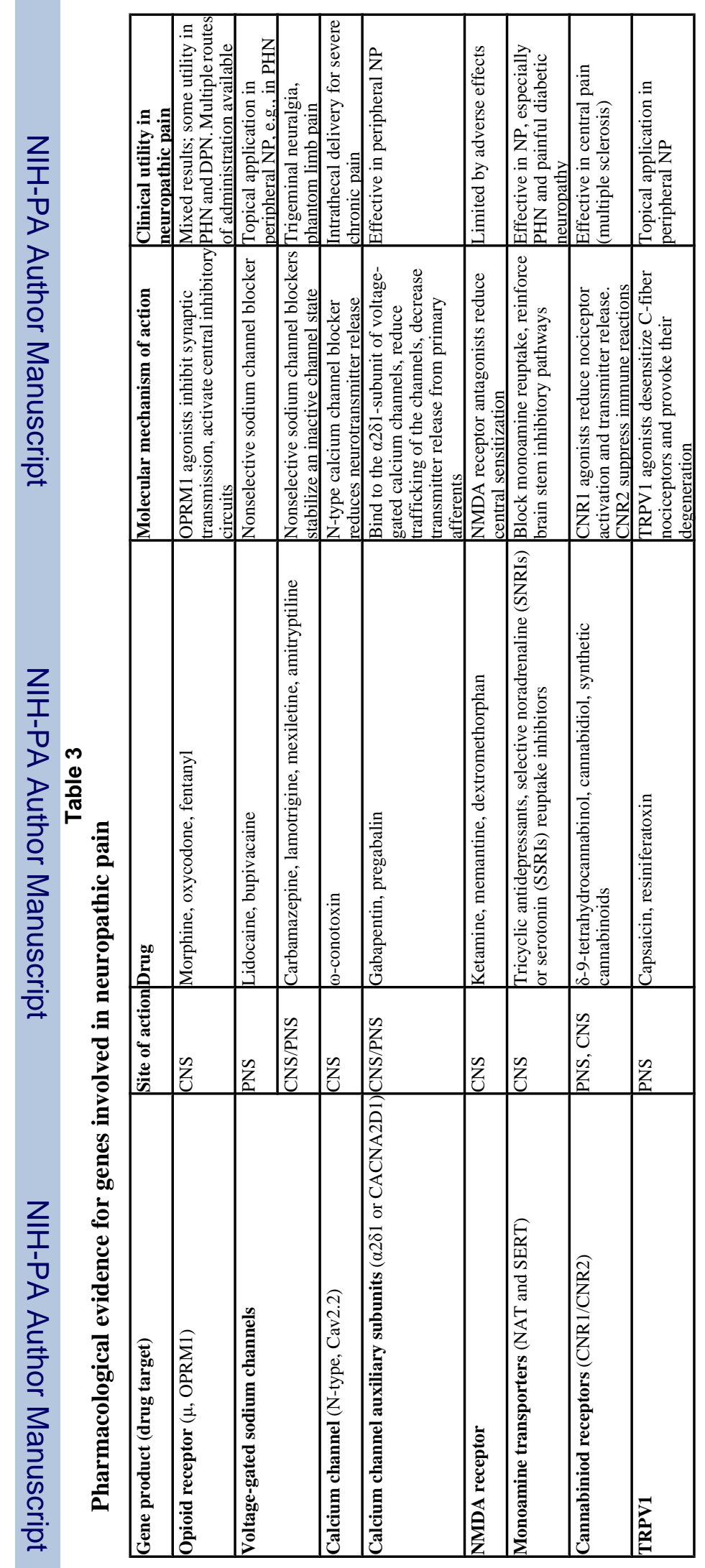

